\title{
ANALISIS STRUKTUR PORTAL BAJA BERTINGKAT GEDUNG PUSAT KESEHATAN UMMAT MUHAMMADIYAH SUMBAWA BESAR
}

\author{
BADARUDDIN, I KOMANG ARIANTA ${ }^{2}$ \\ ${ }^{1}$ Dosen Program Studi Teknik Sipil Fakultas Teknik Universitas Samawa Sumbawa Besar \\ ${ }^{2}$ Mahasiswa Program Studi Teknik Sipil Fakultas Teknik Universitas Samawa Sumbawa Besar
}

\begin{abstract}
Abstrak
Indonesia tengah meningkatkan pembangunan infrastruktur di berbagai daerah, tidak terkecuali di kota-kota kecil seperti kota Sumbawa Besar.Di kota sumbawa besar saat ini tengah gencar melakukan pembangunan, hal ini dibuktikan dengan dibangunnya beberapa gedung bertingkat, seperti gedung kantor DPPK, Gedung IGD sumbawa dan gedung PKU Muhammadiyah.

Gedung PKU Muhammadiyah memiliki fungsi dan tujuan utama untuk meningkatkan taraf kesehatan masyarakat Sumbawa. Diantara gedung-gedung lainnya, Gedung PKU Muhammadiyah memiliki perbedaan yang mencolok yaitu dibangun dengan konstruksi portal menggunakan material baja yang dimana konstruksi portal baja di sumbawa masih cukup jarang digunakan seperti halnya material beton bertulang yang lazim digunakan.

Gedung PKU Muhammadiyah dibangun dengan menggunakan material baja yang dimana strukturnya terdiri dari struktur atap, balok dan kolom. Struktur atap menggunakan material beton dilapisi bondek $8 \mathrm{~mm}$, balok dan kolom masing-masing menggunakan baja WF $500 \times 200 \times 10 \times 16$, WF $400 \times 200 \times 8 \times 13$ untuk balok dan HB $350 \times 357 \times 19 \times 19$ untuk kolom.

Perhitungan portal Gedung PKU Muhammadiyah diperhitungkan sesuai dengan beban yang bekerja antara lain beban hidup, beban mati dan beban gempa.Perhitungan gaya dalam dengan menggunakan metode Takabeya dan sebagai pembanding digunakan aplikasi struktur SAP2000.

Berdasarkan hasil analisis berdasarkan SNI 03-1729-2002 tentang "Tata Cara Perencanaan Struktur Baja Untuk Bangunan Gedung", diketahui bahwaprofil WF 500 x 200 x 10 x 16, WF 400 x $200 \times 8 \times 13$ untuk balok dan HB $350 \times 357 \times 19 \times 19$ sebagai kolom yang digunakan masihdikategorikan aman.
\end{abstract}

Kata Kunci: Konstruksi Portal Baja, Balok, Kolom, Keamanan Profil.

\section{PENDAHULUAN}

Perkembangan perekonomian yang pesat di indonesia akhir-akhir ini memicu pertumbuhan dan pembangunan ekonomi yang pesat, pembangunan tersebut ditandai dengan banyaknya dibangun gedung-gedung bertingkat banyak, dimana bangunantersebut merupakan bangunan tingkat tinggi. Hal tersebut mendorong para perencana bangunan untuk membuat bangunan tingkat tinggi yang tahan gempa. Dimana berdasarkan geografis, Indonesia terletak di antara dua lempeng dunia yang aktif, yaitu Eurasia dan Australia. Hal ini mengkibatkan Indonesia merupakan daerah rawan gempa. Akhir akhir ini gempa yang mengguncang Indonesia terjadi dalam skala besar, tahun 2004, tercatat tiga gempa besar di indonesia yaitu di kepulauan Alor (11 Nov. 7.5Skala rithcer), gempa Papua (26 Nov. 7.1Skala rithcer) dan gempa Aceh (26 Des. 9.2Skala rithcer) yang disertai Tsunami, dan gempa gempa lainnya yang masih sering terjadi hingga saat ini, sehingga mengakibatkan kerusakan pada bangunan tingkat tinggi yang cukup parah. Kondisi itu menyadarkan kita, bahwa Indonesia merupakan daerah rawan terjadinya gempa. Untuk mengurangi resiko bencana yang terjadi diperlukan konstruksi bangunan tahan gempa.

Berlatar belakang alasan tersebut, para perencana konstruksidituntut dapat membuat perencanaan struktur bangunan tingkat tinggi yang aman, agar dapat menahan gaya yang diakibatkan oleh gempa bumi tersebut, khususnya di kota Sumbawa Besar, 
yang dimana tengah gencar melakukan pembangunan di berbagai sisi, dari sisi kesehatan pemerintah maupun pihak swasta tengah melakukan berbagai pembangunan antara lain pemerintah tengah membangun Gedung Instalasi Gawat Darurat di tengahtengah kota Sumbawa, senada dengan pemerintah pihak swastapun ikut dalam proses pembangunan di bidang kesehatan, hal ini dibuktikan dengan dibangunnya Pusat Kesehatan Ummat (PKU) oleh Muhammadiyah, gedung PKUinibertujuan untuk melayani dan meningkatkan taraf kesehatan masyarakat kota Sumbawa Besar. Untuk mengakomodir semua hal tersebut maka haruslah dilakukan proses pembangunan gedung bertingkat yang aman dan nyaman.Bangunan bertingkat yang dibangun pada daerah gempa harus direncanakan mampu bertahan terhadap gempa. Pada struktur bangunan tingkat tinggi harus mampu menahan gaya-gaya vertikal (beban gravitasi), maupun gaya-gaya horizontal (beban gempa).

Struktur yang kuat biasanya memiliki dimensi yang besar tetapi tidak ekonomis jika diterapkan pada bangunan bertingkat tinggi. Perhitungan dimensi biasanya didasarkan pada kolom atau balok struktur yang menanggung beban paling besar. Untuk mendapatkan dimensi penampang yang optimal, maka besar gaya-gaya yang bekerja pada struktur perlu diketahui analisa balok maupun kolom. Dengan adanya pengaruh beban-beban yang bekerja, maka kapasitas momen akan dideformasikan merata ke seluruh elemen. Apabila struktur lentur maka pembebanan pada balok perlu diperhitungkan deformasi momennya. Skripsi ini merupakan studi untuk merencanakan bangunan tingkat tinggi dengan struktur baja. Dimana bangunan tingkat tinggi harus mampu bertahan terhadap gempa yang terjadi.

\section{METODE PENELITIAN}

Skripsi ini menganalisis kinerja portal existing pada perencanaan, dalam hal ini yaitu menganalisis keamanan balok dan kolom existing, pada penelitian ini dilakukan dengan menggunakan metode studi literatur dan dengan melakukan observasi secara langsung dengan disertai referensi-referensi pendukung yang valid.

\section{METODE PENGUMPULAN DATA}

Adapun metode pengumpulan data yang digunakan dalam penulisan Tugas Akhir ini yaitu dengan menggunakan metode studi literatur dan dengan metode observasi secara langsung. Dengan menggunakan studi literatur ini secara langsung dilakukan pencarian referensi guna pengumpulan data-data yang valid dan dengan metode observasi dapat diketahui bentuk portal gedung yang akan ditinjau.

\section{LOKASI PENELITIAN}

Lokasi penelitian dan pengamatan terhadap portal struktur yang diamati adalah Gedung Pusat Kesehatan Ummat Muhammadiyah yang beralamat di Jalan Hasanuddin Kelurahan Bugis Kabupaten Sumbawa Provinsi Nusa Tenggara Barat. :

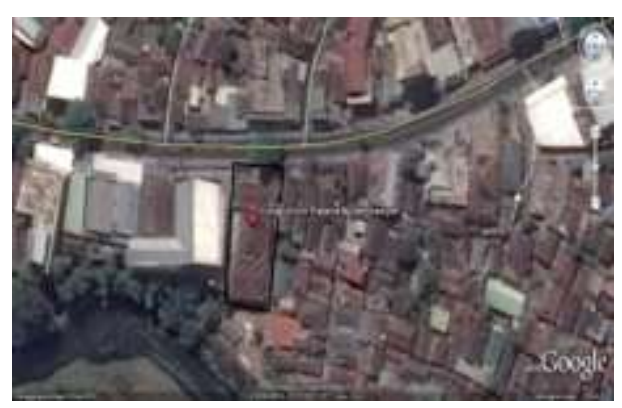

Gambar 1 : Tampak Gedung Via Citra Satelit 2014 ( Google Maps )

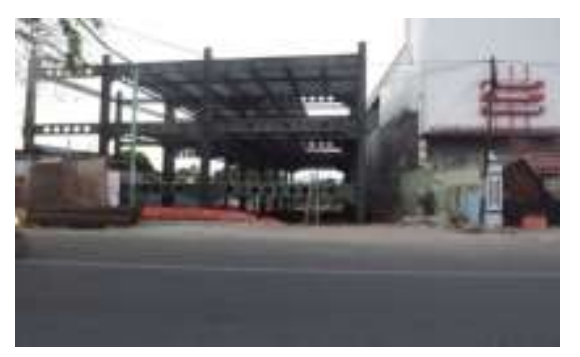

Gambar 2: Tampak Depan Gedung ( Dokumentasi Pribadi ) 


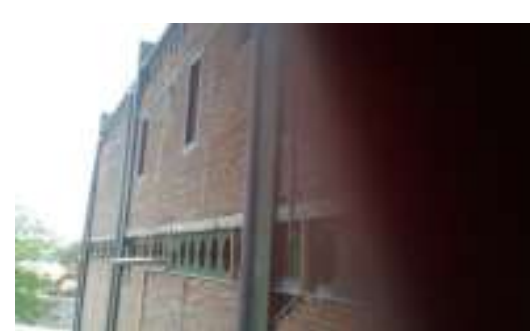

Gambar 3 : Tampak Samping Gedung ( Dokumentasi Pribadi)

\section{JENIS DATA}

Untuk memudahkan proses penelitian skripsi ini maka perlu dilakukan survei pendahuluan guna menentukan datadata mencakup data-data proyek dan kriteria portal, ( panjang, tinggi , lebar dll ). Dalam hal ini data yaitu data primer dan data sekunder, antara lain :

1. Data primer adalah data yang diperoleh secara langsung melalui pengamatan dan observasi, data primer pada penelitian ini antara lain :

$\begin{array}{ll}\begin{array}{ll}\text { Nama } \\ \text { Proyek }\end{array} & \begin{array}{l}\text { : Pembangunan Pusat } \\ \text { Kesehatan Ummat } \\ \text { Muhammadiyah }\end{array} \\ \text { Lokasi } & \text { : Jalan Hasanuddin } \\ \text { Proyek } & \text { Kelurahan Bugis } \\ \text { Fungsi } & \text { : Klinik / Rumah Sakit } \\ \text { Bangunan } & \text { : Swakelola } \\ \text { Pemilik } & \text { Muhammadiyah } \\ \text { Proyek } & \text { : } 3 \text { ( Tiga ) Lantai } \\ \text { Jumlah } & \\ \text { Lantai } & \text { Data Proyek } \\ \text { - Data Dokumentasi Visual } \\ \text { melalui survei lapangan }\end{array}$

2. Data sekunder adalah data penunjang yang diperoleh secara tidak langsung melalui data-data teknis, data perencanaan, standar nasional,buku dan literatur dan lain-laindata sekunder pada penelitian ini antara lain :

- Tata Cara Perencanaan Struktur Baja Untuk Bangunan Gedung SNI 03-1729-2002
- Tata cara perencanaan ketahanan gempauntuk struktur bangunan gedung dan non gedung SNI 1726:2012

- Peraturan Pembebanan Indonesia Untuk Gedung ( PPPURG 1987).

- Gambar Kerja Stuktur Portal Gedung Pusat Kesehatan Ummat Muhammadiyah.

\section{DATA DASAR PERANCANGAN}

Denah gedung terdiri dari 3 bentang balok pada arah $\mathrm{x}$ dengan panjang bentangterbesar $7.5 \mathrm{~m}$ dan $6.9 \mathrm{~m}$, dan 6 bentang balok pada arah y dengan panjang bentangterbesar $7.5 \mathrm{~m}$ dan $5.32 \mathrm{~m}$. Denah gedung selengkapnya seperti dalam Gambar 4.

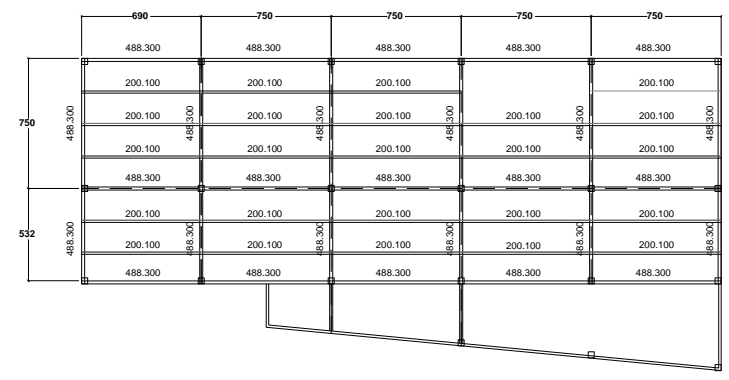

Gambar 4 : Denah Portal Gedung ( Data Perencanaan )

\section{MODEL STRUKTUR}

Struktur portal mempunyai 3 tingkat (story) termasuk atap dengan tinggi antartingkat bervariasi dengan jarak antar kolom 5,5 m, 6,9 m dan 7,5 m. Model struktur selengkapnya seperti dalam gambar 5 dan gambar 6 .

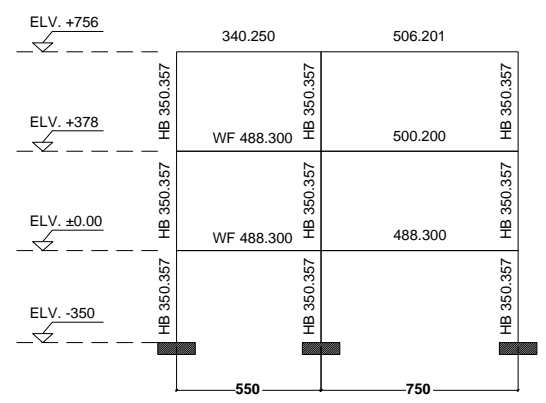

Gambar 5 : Portal Arah Melintang (Data Perencanaan ) 


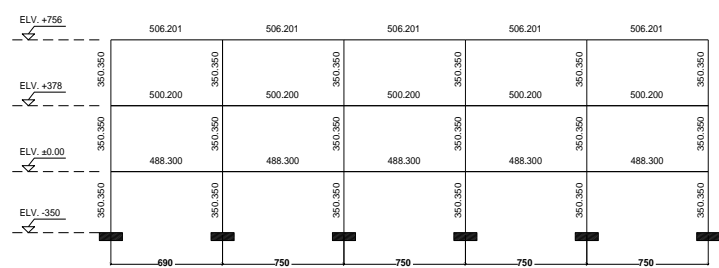

Gambar 6 : Portal Arah Memanjang (Data Perencanaan )

\section{SPESIFIKASI DAN DATA STRUKTUR}

Dari hasil survei lapangan dan data-data yang diperoleh dari pelaksana maka beberapa hal dapat dijabarkan sebagai berikut :

1. Gedung terdiri dari 3 ( tiga ) lantai dan fungsi gedung sebagai Rumah Sakitdengan beban hidup $250 \mathrm{~kg} /$ $\mathrm{m}^{2}$ (PPPURG 1987).

2. Struktur utama (balok dan kolom) menggunakan bahan baja, Mutu Baja BJ-41

\section{TAHAPAN PERENCANAAN}

Suatu perencanaan harus dilakukan dengan sistematika yang jelas dan teratursehingga hasilnya dapat dipertanggung-jawabkan. Oleh karena itu, penelitian inidibagi dalam beberapa tahap sebagai berikut :

\section{Tahap I}

Tahap persiapan. Persiapan awal dilakukan dengan mengumpulkan data dan informasi yangmendukung perancangan struktur, dalam hal ini meliputi gambar kerja, data-data proyek, dan referensi-referensi penunjang dalam perencanaan seperti buku-buku (daftar buku tercantum dalam daftar pustaka) dan peraturan Perhitungan struktur baja dalam hal ini SNI-baja 2002. Selain itu pada tahap persiapan dilakukan penentuan profil balok dan kolom existing pada portal Gedung PKU Muhammadiyah.

2. Tahap II

Berdasarkan data-data pada tahap persiapan, Berdasarkan data portal yang meliputi data profil balok dan kolom existing serta bentang (panjang dan lebar) serta ketinggian portal maka langkah selanjutnya dilakukan proses Analisis Statika terhadap model struktur dengan bantuan aplikasi SAP2000 dan perhitungan manual menggunakan metode Takabeya, (perhitungan statika tercantum pada bagian lampiran-lampiran) hal ini dilakukan guna memperoleh besaran gaya dalam yang bekerja seperti Gaya momen, gaya geser, dan gayatekan atau gaya tarik pada struktur portal terhadap bebanbeban yang bekerja(beban hidup, beban mati dan beban gempa).Gaya-gaya ini adalah dasar perhitungan untuk mengetahui keamanan dari profil balok dan kolom yang digunakan.

3. Tahap III

Setelah gaya dalam ditentukan pada tahap II dan dihasilkan gaya momen, Lintang dan gaya normal maka langkah selanjutnya yaitu Kontrol Keamanan profil kolom dan balok existingterhadap momen, gaya geser, dan gaya tekan atau gaya tarikyang diperoleh dari analisa statika. Pada proses penentuan kekuatan profil yang digunakan langkah pertama yaitu menentukan keamanan profil balok existing, langkah perhitungannya yaitu :

- Perhitungan Centre of Gravity ( Pers. 2.27)

- Cek Zx terhadap Sx ( Pers. 2.26)

- Cek kekompakan profil ( Pers. 2.28 S/D Pers.2.29)

- Cek kapasitas berdasarkan Flange Local Buckling ( Pers. 2.30)

- Cek kapasitas berdasarkan Local Torsional Buckling ( Tabel 2.12 )

- Kuat Lentur Nominal pada kondisi Local Torsional Buckling (Pers. 2.38)

- Kuat Geser ( Pers. 2.42 S/D Pers.2.48) 
- Lendutan ( Pers. 2.49)

Setelah itu yaitu menentukan keamanan profil Kolomexisting, langkah perhitungannya yaitu :

- Perhitungan Centre of Gravity ( Pers. 2.27)

- Cek Zx terhadap Sx (Pers. 2.26 )

- Cek kekompakan profil (Pers. $2.28,2.30$ dan Pers. $2.56 \mathrm{~S} / \mathrm{D} 2.60)$

- Cek kapasitas berdasarkan Flange Local Buckling ( Pers. 2.39)

- Cek kapasitas berdasarkan Local Torsional Buckling ( Tabel. 2.12 )

- Kuat Lentur Nominal pada kondisi Local Torsional Buckling (Pers.2.39)

- Faktor Pembesaran Momen ( Pers. 2.63 S/D 2.65 )

- Momen Maksimum Terfaktor ( Pers. 2.61)

- Menentukan Parameter Kelangsingan ( Pers. 2.53)

- Menentukan Nu / $\varnothing \mathrm{Nn}($ Pers. 2.51 dan 2.54 )

- Interaksi aksial momen ( Pers. 2.54 dan 2.55 )

4. Tahap IV

Setelah dilakukan perhitungan keamanan profil maka langkah selanjutnya yaitu Tahap pengambilan kesimpulan. Pada tahap ini, dengan berdasarkan hasilperhitungan pada tahap analisis, maka dilakukan proses penyimpulan, penyimpulan dilakukan dengan merekapitulasi seluruh hasil perhitungan keamanan profil balok dan kolom kedalam tabel. (tabel 4.10 sampai dengan tabel 4.13), hal ini dilakukan guna memudahkan proses pembacaan skripsi ini.

\section{BAGAN ALIR PENELITIAN}

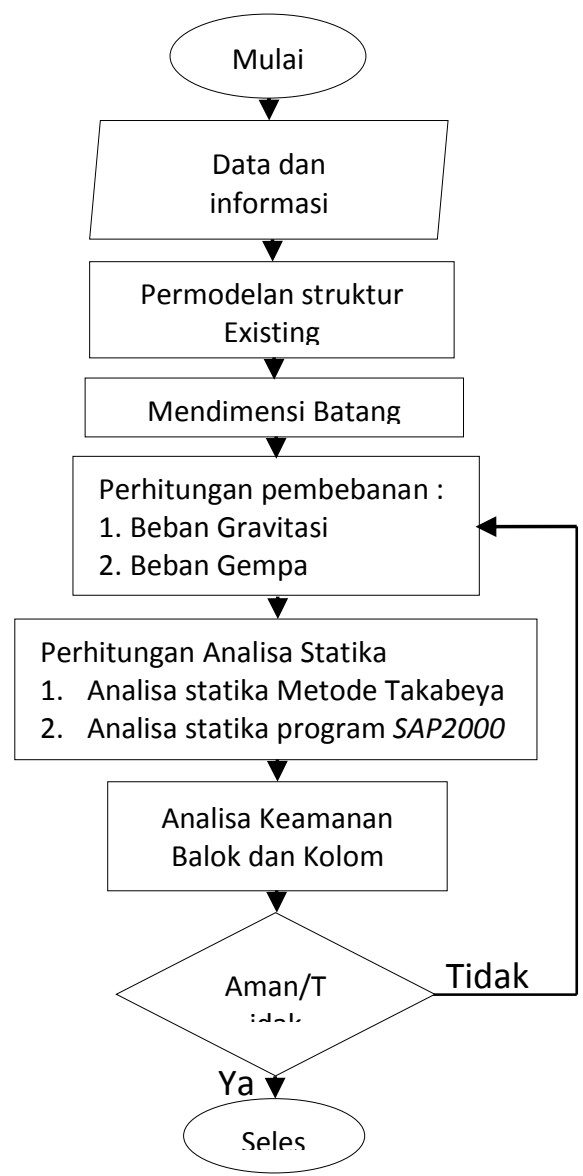

Gambar 7 : Bagan Alir Penelitian

\section{HASIL DAN PEMBAHASAN \\ DATA UMUM PORTAL}

\section{Data Perencanaan :}

Kegunaan Bangunan :RUMAH SAKIT Jenis Tanah: TANAH LUNAK (Berdasarkan Sondir)

Profil yang dipakai :

- KOLOM :HB.350.357.19.19

( Data Perencanaan )

- BALOK :WF.500.200.10.16 ( Data Perencanaan )

- WF.400.200.8.13 ( Data Perencanaan)

- Plat Lantai : BONDEK $8 \mathrm{~mm}$ (Data Perencanaan )

- Tebal plat : $10,5 \mathrm{~cm}=0,105 \mathrm{~m}$ (Data Perencanaan)

- Berat Beton Bertulang : $24 \mathrm{KN} / \mathrm{m}^{3}$ ( PPPURG 1987)

Dan Beban-Beban Yang lain bersumber dari PPPURG 1987 
- Mutu Baja: BJ-41

- Fu: $410 \mathrm{Mpa}$ (SNI $03-1729-2002$

- Fy: 250Mpa(SNI 03-1729-2002
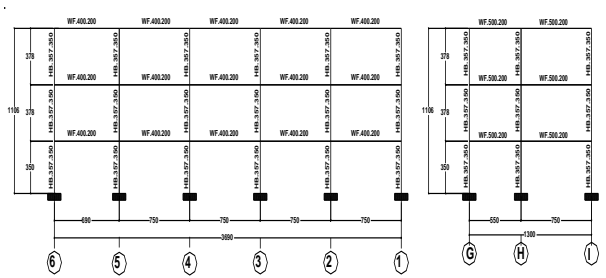

Gambar 8: Gambar Portal dan Denah Portal (Data Existing)

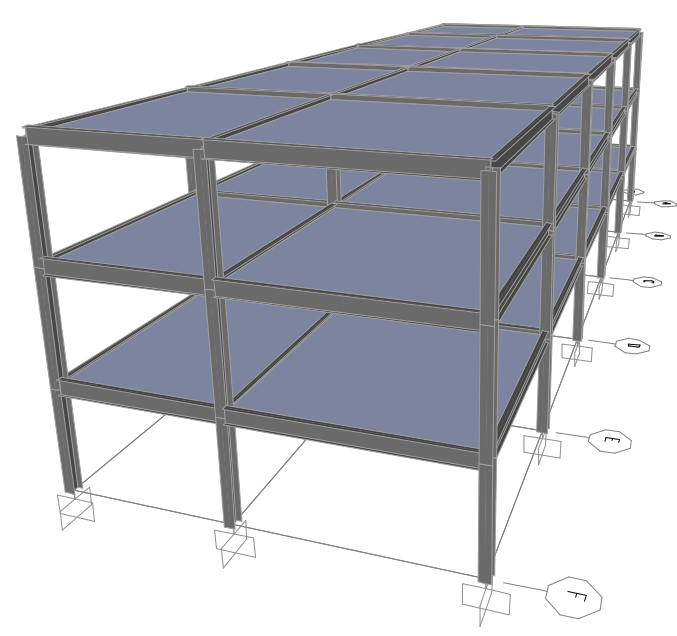

Gambar 9 : TampakPerspektif Portal (Data SAP2000)

\section{Perhitungan Pembebanan portal}

Data Teknis Perencanaan Pembebanan Portal ( PPPURG 1987 )

- Berat beton bertulang : 2400 $\mathrm{Kg} / \mathrm{m}^{3} \quad: 24 \mathrm{KN} / \mathrm{m}^{3}$

- Berat penutup lantai keramik : $24 \mathrm{Kg} / \mathrm{m}^{2} \quad: 0,24 \mathrm{KN} / \mathrm{m}^{2}$

- Berat adukan semen per $\mathrm{cm}$ tebal $: 21 \mathrm{Kg} / \mathrm{m}^{2}: 0,21 \mathrm{KN} / \mathrm{m}^{2}$

- Pasangan Bata Merah 1/2 Batu : $250 \mathrm{Kg} / \mathrm{m}^{2}: 2,5 \mathrm{KN} / \mathrm{m}^{2}$

- Berat pasir kondisi lembab : $1850 \mathrm{Kg} / \mathrm{m}^{3} \quad: 18,5 \mathrm{Kg} / \mathrm{m}^{3}$

- Berat plafon \& penggantung : $18 \mathrm{Kg} / \mathrm{m}^{2} \quad: 0,18 \mathrm{KN} / \mathrm{m}^{2}$

- Berat Instalasi Air dan Listrik : $25 \mathrm{Kg} / \mathrm{m}^{2} \quad: 0,25 \mathrm{KN} / \mathrm{m}^{2}$

- Beban Bondek : 7,4Kg/ $/ \mathrm{m}^{2}$ : $0,074 \mathrm{KN} / \mathrm{m}^{2}$
- Beban hidup untuk gedung Rumah Sakit: $250 \mathrm{Kg} / \mathrm{m}^{2}$ : $2,5 \mathrm{KN} / \mathrm{m}^{2}$

Dari data diatas maka beban dapat dihitung sebagai berikut :

\section{BEBAN ATAP}

Beban mati ( $q D$ )

- Plat beton $(\mathrm{t}=10.5 \mathrm{~cm}) \quad=$ $0,105.24=2,52$

- Plat Bondek =0,074 $=0,074 \mathrm{KN} / \mathrm{m}$

- Berat plafond \& penggantung $=0,18$ $=0,18 \mathrm{KN} / \mathrm{m}$

- Berat Instalasi Air dan Listrik $=0,25$ $=0,25 \mathrm{KN} / \mathrm{m}$

- Berat Air hujan $=0,020 \cdot 10=\underline{0,2 \mathrm{KN} / \mathrm{m}}$

$\mathrm{qL}$ $=2,5 \mathrm{KN} / \mathrm{m}$

Beban berfaktor

$$
\begin{aligned}
& =1,2 q_{D}+1,6 q_{L} \\
& =1,2 \cdot 3,224+1,6 \cdot 2,5 \\
& =7,869 \mathrm{KN} / \mathrm{m}
\end{aligned}
$$

Berikut ini data perencanaan denah dan lain-lain :

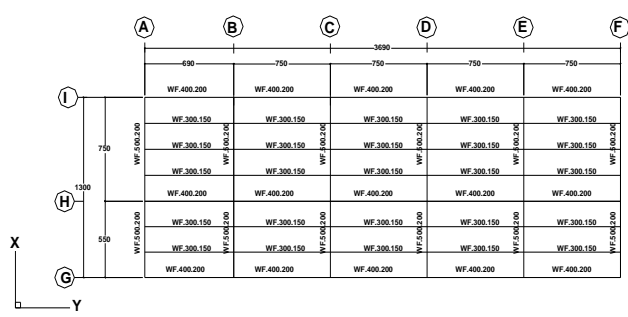

Gambar 10 : Denah Lantai 3 / Atap

( Data Existing )

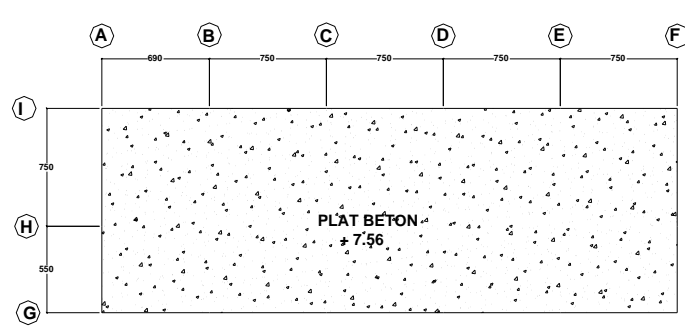

Gambar 11 : Denah Balok Lantai 3 / Atap (Data Existing ) 


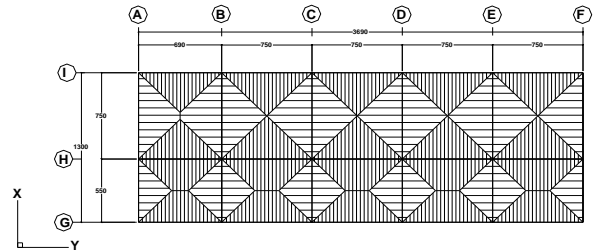

Gambar 12 : Pembebanan Lantai 3 / Atap ( Data Perhitungan)

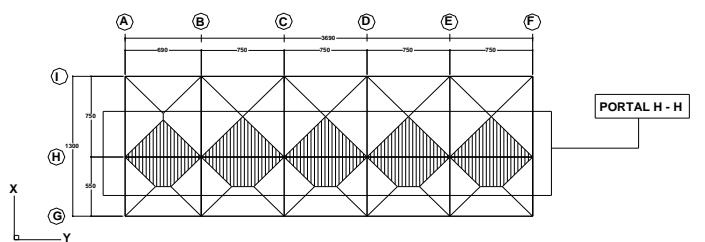

Gambar 13 : Pembebanan Arah Y - Y Lantai 3 / Atap ( Data Perhitungan )

\section{BEBAN LANTAI 1 \& 2}

Beban mati ( qD)

- Plat beton $(\mathrm{t}=10.5 \mathrm{~cm})=$ $0,105.24=2,52 \mathrm{KN} / \mathrm{m}$

- $\quad$ Plat Bondek =0,074=0,074KN $/ \mathrm{m}$

- $\operatorname{Keramik}(t=1 \mathrm{~cm})=1.0,24$ $=0,24 \mathrm{KN} / \mathrm{m}$

- $\operatorname{Spesi}(\mathrm{t}=2 \mathrm{~cm})=2 \cdot 0,21=$ $0,42 \mathrm{KN} / \mathrm{m}$

- Berat plafond \& penggantung $=0,18=0,18 \mathrm{KN} / \mathrm{m}$

- Berat Instalasi Air dan Listrik $=0,25=\underline{0,25 \mathrm{KN} / \mathrm{mm}}$

Beban hidup $\left(q_{L}\right)$ $\mathrm{qL}=2,5 \mathrm{KN} / \mathrm{m}$

Beban berfaktor $=1,2 q_{D}+1,6 q_{L}$ $=1,2 \cdot 3,684+1,6 \cdot 2,5$ $=8,42 \mathrm{KN} / \mathrm{m}$
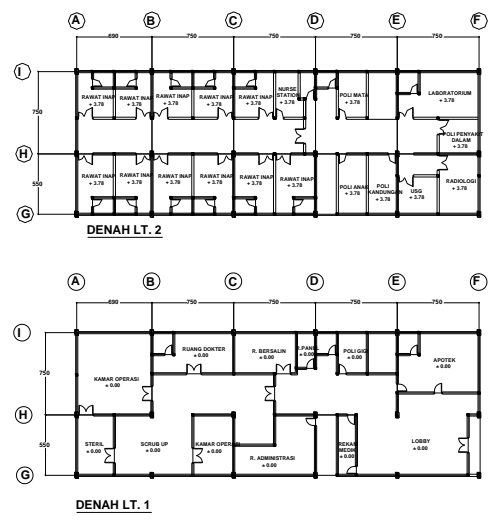

Gambar 14 : Denah Lantai 1 ( b ) \& Denah Lantai 2 ( a (Data Existing )

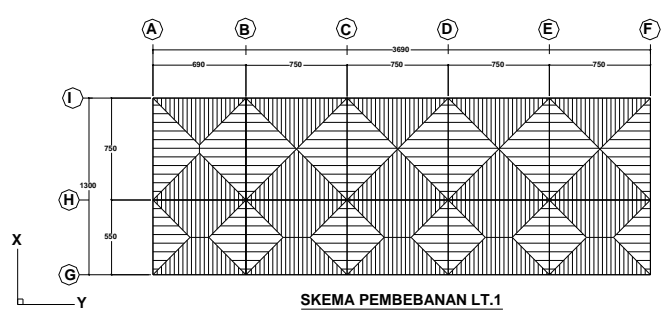

Gambar 15 : Denah Balok Lantai 1 \& Lantai 2 ( Data Existing )

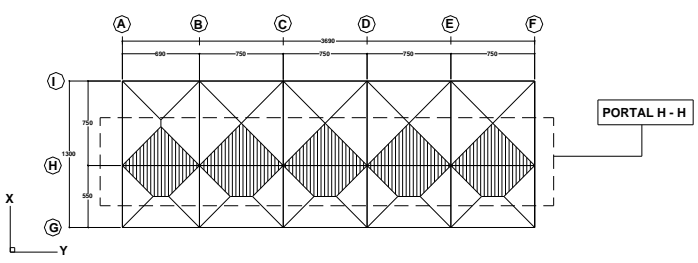

Gambar 16 : Skema Pembebanan Lantai 1 \& Lantai 2 ( Data Perhitungan )

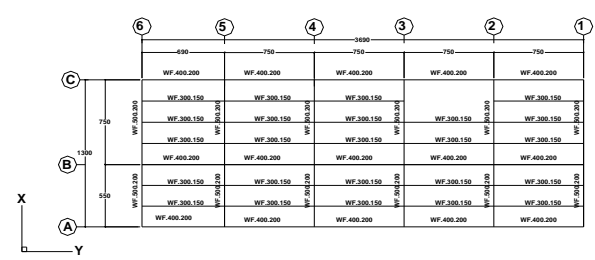

Gambar 17 : Skema Pembebanan Lantai 1 \& Lantai 2 Arah $Y-Y$ ( Data Perhitungan )

\section{Analisa Pembebanan Yang Bekerja}

Dalam menganalisa berbagai beban yang berkerja pada suatu portal, terdapat metode pembebanan yaitu metode pembebanan amplop. Dalam metode tersebut terdapat dua bentuk pembebanan yaitu beban segitiga dan beban trapesium, dalam hal ini untuk memudahkan perhitungannya maka kedua beban tersebut diubah kedalam bentuk beban merata biasa dengan menggunakan leq ( beban equivalen), berikut perhitungannya :

\section{a. Perhitungan $I_{\text {eq }}($ Beban segitiga )} Portal Melintang $(X-X)$ :

Setelah dilakukan perumusan konversi beban segitiga ke beban equivalen maka dapat ditentukan perhitungan pembebanan pada portal, dalam hal ini diambil contoh pada portal arah X-X pada bentang 7,5 meter dan 5,5 meter , 
berikut perhitungannya

berdasarkan persamaan ( 2.4 ) :

Untuk bentang 7,5 meter :

$$
\begin{aligned}
\mathrm{I}_{\mathrm{eq}} & =\frac{1}{3} \cdot 7,5 \\
& =2,5 \text { Meter }
\end{aligned}
$$

Untuk bentang 5,5 meter :

$$
\begin{aligned}
\mathrm{I}_{\mathrm{eq}} & =\frac{1}{3} \cdot 5,5 \\
& =1,83 \mathrm{Meter}
\end{aligned}
$$

b. Perhitungan $\quad \mathrm{I}_{\text {eq }}$ (Beban segitiga) Portal Memanjang $(\mathbf{Y}-\mathbf{Y})$ :

Setelah dilakukan perumusan konversi beban segitiga ke beban equivalen maka dapat ditentukan perhitungan pembebanan pada portal, dalam hal ini diambil contoh pada portal arah $\mathrm{Y}-\mathrm{Y}$ pada bentang 7,5 meter dan 6,9 meter , berikut perhitungannya, berdasarkan persamaan ( 2.4 ):

$$
\text { Untuk bentang 6,9 }
$$
meter:

$$
\begin{aligned}
& \mathrm{I}_{\text {eq }}=\frac{1}{3} \cdot 6,9 \\
& =2,30 \text { Meter }
\end{aligned}
$$

Untuk bentang 7,5 meter :

$$
\begin{aligned}
& \mathrm{I}_{\text {eq }}=\frac{1}{3} \cdot 7,5 \\
& =2,50 \text { Meter }
\end{aligned}
$$

c. Perhitungan

Trapesium)

$\mathrm{I}_{\text {eq }}$ (Beban

Memanjang

Portal

$$
(\mathbf{Y}-\mathbf{Y}) \text { : }
$$

Setelah

dilakukan perumusan konversi beban trapesium ke beban equivalen maka dapat ditentukan perhitungan pembebanan pada portal, dalam hal ini diambil contoh pada portal arah $\mathrm{Y}-\mathrm{Y}$ pada bentang 7,5 meter dan 6,9 meter , berikut perhitungannya berdasarkan persamaan ( 2.8 ) :

Untuk bentang 6,9 meter :

$$
\begin{gathered}
\mathrm{I}_{\mathrm{eq}}= \\
\frac{1}{6} \cdot 5,5 \cdot\left\{3-4\left(\frac{5,5}{2 \cdot 6,9}\right)^{2}\right\} \\
=2,17 \text { Meter }
\end{gathered}
$$

Untuk bentang 7,5 meter:

$$
\begin{gathered}
\mathrm{l}_{\mathrm{eq}}= \\
\frac{1}{6} \cdot 5,5 \cdot\left\{3-4\left(\frac{5,5}{2 \cdot 7,5}\right)^{2}\right\} \\
=2,26 \text { Meter }
\end{gathered}
$$

Pembebanan Portal Arah Y - Y ( Memanjang )

Setelah

dilakukan perhitungan konversi ke beban Qeq maka langkah selanjutnya yaitu perhitungan beban yang bekerja arah $\mathrm{Y}-\mathrm{Y}$, dalam hal ini akan dilakukan perhitungan beban konversi pada arah simpul A - B pada batang 13-14, setelah dilakukan 1 perhitungan maka beban selanjutnya akan direkapitulasi menjadi sebuah tabel, berikut perhitungannya :

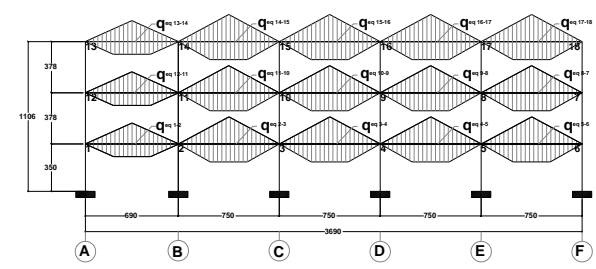

Gambar 18 : Pembebanan Portal Akibat beban Segitiga \& Trapesium

( Data Perhitungan)

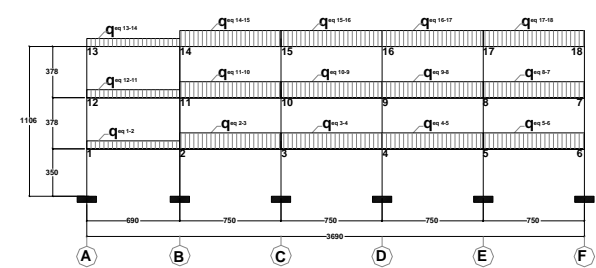

Gambar 19 : Konversi Pembebanan Portal Akibat beban Segitiga \& Trapesium Menjadi Qeq ( Data Perhitungan )

\section{Beban merata A -B ( Atap )}

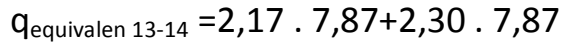

$$
=35,15 \mathrm{KN} / \mathrm{m}
$$

Maka Total Beban merata $13-14$

$($ Atap $)=35,15 \mathrm{KN} / \mathrm{m}$ 
Dari contoh perhitungan diatas, guna mempersingkat hitungan dan memudahkan proses pembacaan maka hasil perhitungan pada lantailantai selanjutnya dilakukan proses rekapitulasi beban gempa yang bekerja, hasil rekapitulasi beban dicantumkan pada tabel dibawah ini:

Tabel 1 : Beban $Q$ equivalen pada Lantai I , II \& III

\begin{tabular}{|c|c|c|c|c|c|c|}
\hline \multirow{2}{*}{ No. } & \multicolumn{2}{|c|}{ LANTAI I } & \multicolumn{2}{c|}{ LANTAI II } & \multicolumn{2}{c|}{ LANTAI III ( Atap ) } \\
\cline { 2 - 7 } & BATANG & Qekivalen & BATANG & Qekivalen & BATANG & Qekivalen \\
\hline 1 & $1-2$ & 37,62 & $7-8$ & 40,06 & $13-14$ & 35,15 \\
\hline 2 & $2-3$ & 40,06 & $8-9$ & 40,06 & $14-15$ & 37,43 \\
\hline 3 & $3-4$ & 40,06 & $9-10$ & 40,06 & $15-16$ & 37,43 \\
\hline 4 & $4-5$ & 40,06 & $10-11$ & 40,06 & $16-17$ & 37,43 \\
\hline 5 & $5-6$ & 40,06 & $11-12$ & 37,62 & $17-18$ & 37,43 \\
\hline
\end{tabular}

Pembebanan Portal Arah X - X I Melintang )

Setelah dilakukan perhitungan konversi ke beban Qeq maka langkah selanjutnya yaitu perhitungan beban yang bekerja arah $\mathrm{X}-\mathrm{X}$, dalam hal ini akan dilakukan perhitungan beban konversi pada arah simpul $\mathrm{G}-\mathrm{H}$ pada batang 25-26 ( Lantai Atap), setelah dilakukan 1 perhitungan maka beban selanjutnya akan direkapitulasi menjadi sebuah tabel, berikut perhitungannya :

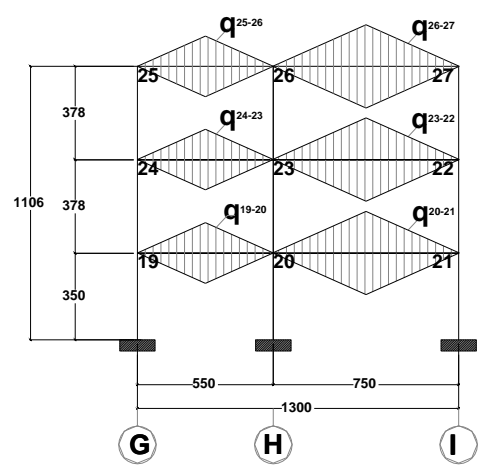

Gambar 20 : Pembebanan Portal Akibat beban Segitiga \&Trapesium

( Data Perhitungan )

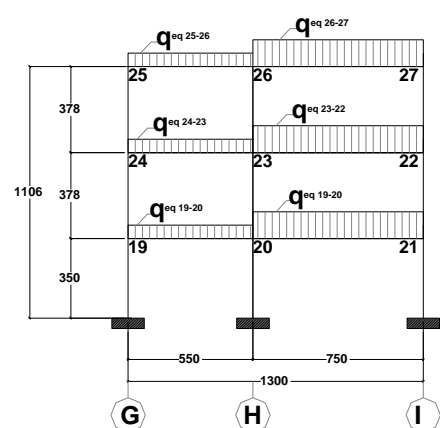

Gambar 21 : Konversi Pembebanan Portal Akibat beban Segitiga \& Trapesium Menjadi Qeq ( Data Perhitungan )

\section{Beban merata G -H ( Atap )}

$q_{\text {equivalen25-26 }}=1,83 \cdot 7,87+1,83$. 7,87 $=28,85 \mathrm{KN} / \mathrm{m}$

Total Beban merata 6 -5 ( Atap) $=28,852 \mathrm{KN} / \mathrm{m}$

Dari contoh perhitungan diatas, guna mempersingkat hitungan dan memudahkan proses pembacaan maka hasil perhitungan pada lantai-lantai selanjutnya dilakukan proses rekapitulasi beban gempa yang bekerja, hasil rekapitulasi beban dicantumkan pada tabel dibawah ini:

Tabel 2 : Beban Q equivalen pada Lantai I

\begin{tabular}{|c|c|c|c|c|c|c|}
\hline \multirow{2}{*}{ No. } & \multicolumn{2}{|c|}{ LANTAII } & \multicolumn{2}{c|}{ LANTAI II } & \multicolumn{2}{c|}{ LANTAI III ( Atap) } \\
\cline { 2 - 7 } & BATANG & Qekivalen & BATANG & Qekivalen & BATANG & Qekivalen \\
\hline 1 & $19-20$ & 30,88 & $22-23$ & 30,88 & $25-26$ & 28,85 \\
\hline 2 & $20-21$ & 42,10 & $23-24$ & 42,10 & $26-27$ & 39,34 \\
\hline
\end{tabular}

\section{Perhitungan Beban Akibat Gempa}

Kota Sumbawa Besar adalah salah satu kota yang terdapat di provinsi NTB (Nusa Tenggara Barat), adapun Lokasi bangunan Portal berada pada koordinat 8.497790900424045 LS dan 117.42153469473124 BT, berdasarkan data-data diatas dapat dilakukan perhitungan beban gempa menggunakan SK-SNI 1726:2012 tentang "Tata Cara Perencanaan Ketahanan Gempa Untuk Struktur Bangunan Gedung Dan Non Gedung " :

Data Umum :

- Pemanfaatan gedung:RUMAH SAKIT

- Lokasi: Kota Sumbawa Besar 
Tabel 3 : Koefisien situs, Fa

\begin{tabular}{|c|c|c|c|c|c|c|c|c|c|}
\hline \multirow{2}{*}{$\begin{array}{c}\text { KELAS } \\
\text { SITUS }\end{array}$} & \multicolumn{8}{|c|}{ Parameter Respons spektral percepatan gempa (MCEr) Terpetakan pada periode pendetk, } \\
\cline { 2 - 11 } & $\mathrm{Ss} \leq 0.25$ & - & $\mathrm{Ss}=0.5$ & - & $\mathrm{Ss}=0.75$ & - & $\mathrm{Ss}=1.0$ & $\mathrm{Ss}=1,2$ & $\mathrm{Ss} \geq 1.25$ \\
\hline $\mathrm{SA}$ & 0,8 & - & 0,8 & - & 0,8 & - & 0,8 & 0,80 & 0,8 \\
\hline SB & 1,0 & - & 1,0 & - & 1,0 & - & 1,0 & 1,00 & 1,0 \\
\hline SC & 1,2 & - & 1,2 & - & 1,1 & - & 1,0 & 1,00 & 1,0 \\
\hline SD & 1,6 & - & 1,4 & - & 1,2 & - & 1,1 & 1,02 & 1,0 \\
\hline SE & 2,5 & - & 1,7 & - & 1,2 & - & 0,9 & 0,90 & 0,9 \\
\hline SF & \multicolumn{70}{|c|}{ SSb } \\
\hline
\end{tabular}

Karena Ss = 1,2 maka Rumus Interpolasi digunakan guna memperoleh data $\mathrm{Fa}$ berdasarkan persamaan ( 2.14 ):

$$
\begin{aligned}
Y & =Y 1+\frac{X-X 1}{X 2-X 1} Y 2-Y 1 \\
Y & =0,9+\frac{0,9-0,9}{1,25-1} 1,0-0,9 \\
& =0,90
\end{aligned}
$$

berdasarkan data Ss dapat diperoleh nilai Fv pada tabel SNI SNI 1726:2012.

\begin{tabular}{|c|c|c|c|c|c|c|c|c|c|}
\hline \multirow{2}{*}{$\begin{array}{l}\text { KELAS } \\
\text { SITUS }\end{array}$} & \multicolumn{9}{|c|}{$\begin{array}{l}\text { Parameter Respons spektral percepatan gempa ( } \mathrm{MCEr} \text { ) Terpetakan pada periode pendetk, } \\
\qquad \mathrm{T}=1 \text { Detik, } \mathrm{S1}\end{array}$} \\
\hline & $\mathrm{S} 1 \leq 0,1$ & . & $\mathrm{Sl}=0,2$ & - & $\mathrm{Sl}=0,3$ & . & $\mathrm{S} 1=0,4$ & . & $\mathrm{S} 1 \geq 0.5$ \\
\hline SA & 0,8 & - & 0,8 & - & 0,8 & - & 0,8 & - & 0,8 \\
\hline SB & 1,0 & - & 1,0 & - & 1,0 & - & 1,0 & - & 1,0 \\
\hline SC & 1,7 & - & 1,6 & . & 1,5 &. & 1,4 & - & 1,3 \\
\hline SD & 2,4 & $\cdot$ & 2,0 & - & 1,8 & - & 1,6 & - & 1,5 \\
\hline SE & 3,5 & - & 3,2 & . & 2,8 &. & 2,4 & . & 2,4 \\
\hline $\mathrm{SF}$ & & & & & SSb & & & & \\
\hline
\end{tabular}
$\mathrm{S}_{1}=0,4$

Tabel 4 : Koefisien situs, Fv

Dari contoh perhitungan diatas, guna mempersingkat hitungan dan memudahkan proses pembacaan maka hasil perhitungan pada lantai-lantai selanjutnya dilakukan proses rekapitulasi beban gempa yang bekerja, hasil rekapitulasi beban dicantumkan pada tabel dibawah ini :

Tabel 5 : Tabel Rekapitulasi Koefisien situs, Fa \& Fv

\begin{tabular}{|c|c|c|}
\hline $\begin{array}{c}\text { KELAS } \\
\text { SITUS }\end{array}$ & Fa & Fv \\
\hline SA & 0,80 & 0,8 \\
\hline SB & 1,00 & 1 \\
\hline SC & 1,00 & 1,4 \\
\hline SD & 1,02 & 1,6 \\
\hline SE & 0,90 & 2,4 \\
\hline
\end{tabular}

Menghitung Parameter Percepatan Spektral $\mathrm{S}_{\mathrm{DS}}, \mathrm{S}_{\mathrm{D} 1} \&$ Spectrum Respons Design
A. Menghitung Parameter Percepatan Spektral $\mathrm{S}_{\mathrm{DS}}$ Dan $\mathrm{S}_{\mathrm{D} 1}$ :

Parameter percepatan spektral desain untuk perioda pendek, $S_{D S}$ dan pada perioda 1 detik, $S_{D 1}$, dapat ditentukan melalui persamaan (2.15) dan persamaan ( 2.16 ) berikut ini :

\begin{tabular}{|l|l|l|l|}
\hline $\mathrm{S}_{\mathrm{MS}}$ & $=$ & $\mathrm{Fa}$ & $\mathrm{S}_{\mathrm{S}}$ \\
\hline $\mathrm{S}_{\mathrm{M} 1}$ & $=$ & $\mathrm{Fv}$ & $\mathrm{S}_{1}$ \\
\hline $\mathrm{S}_{\mathrm{DS}}$ & $=$ & $2 / 3$ & $\mathrm{~S}_{\mathrm{MS}}$ \\
\hline $\mathrm{S}_{\mathrm{D} 1}$ & $=$ & $2 / 3$ & $\mathrm{~S}_{\mathrm{M} 1}$ \\
\hline
\end{tabular}

Tabel 6 : Tabel Rekapitulasi Koefisien

\begin{tabular}{|c|c|c|c|c|}
\multicolumn{5}{c}{ situs, $\mathrm{S}_{\mathrm{MS}} \& \mathrm{~S}_{\mathrm{M} 1}, \mathrm{~S}_{\mathrm{DS}} \& \mathrm{~S}_{\mathrm{D} 1}$} \\
\hline $\begin{array}{c}\text { KELAS } \\
\text { SITUS }\end{array}$ & $\mathrm{S}_{\mathrm{MS}}$ & $\mathrm{S}_{\mathrm{M} 1}$ & $\mathrm{~S}_{\mathrm{DS}}$ & $\mathrm{S}_{\mathrm{D} 1}$ \\
\hline SA & 0,96 & 0,32 & 0,64 & 0,21 \\
\hline SB & 1,20 & 0,40 & 0,80 & 0,27 \\
\hline SC & 1,20 & 0,56 & 0,80 & 0,37 \\
\hline SD & 1,22 & 0,64 & 0,82 & 0,43 \\
\hline SE & 1,08 & 0,96 & 0,72 & 0,64 \\
\hline
\end{tabular}

B. Perhitungan Spectrum ResponsDesign :

Spektrum respons desain diperlukan untuk membentuk kurva spektrum respons desain, dalam perhitungannya dibutuhkan beberapa variabel antara lain parameter respons spektral percepatan desain pada perioda pendek $\left(S_{D S}\right)$ dan parameter respons spektral percepatan desain pada perioda 1 detik $\left(S_{D 1}\right)$ serta perioda getar fundamental struktur ( $T$ ), berikut perhitungannya berdasarkan persamaan ( 2.17 ) sampai dengan persamaan ( 2.20$)$, :

$$
\begin{gathered}
T_{0}=0,2 \frac{S_{D 1}}{S_{D S}} \\
T_{S}=\frac{S_{D 1}}{S_{D S}} \\
T<T_{0} \\
S a=S_{D S}\left(0,4+0,6 \frac{T}{T_{0}}\right) \\
T_{0}<T<T s \\
\text { Sa }=S_{D S} \\
T>T s \\
\text { Sa }=\frac{S_{D 1}}{T}
\end{gathered}
$$


Tabel 7 : Tabel Rekapitulasi T \& Sa

\begin{tabular}{|c|c|}
\hline \multicolumn{2}{|c|}{$\begin{array}{c}\text { TANAH LUNAK } \\
\text { ( SE ) }\end{array}$} \\
\hline T ( s ) & Sa ( g ) \\
\hline $\mathbf{0}$ & 0,288 \\
\hline $\mathbf{0 , 1 7 8}$ & 0,720 \\
\hline $\mathbf{0 , 2 8}$ & 0,720 \\
\hline $\mathbf{0 , 3}$ & 0,720 \\
\hline $\mathbf{0 , 4}$ & 0,720 \\
\hline $\mathbf{0 , 5}$ & 0,720 \\
\hline $\mathbf{0 , 6}$ & 0,720 \\
\hline $\mathbf{0 , 8 8 9}$ & 0,720 \\
\hline $\mathbf{1 , 1}$ & 0,582 \\
\hline $\mathbf{1 , 6}$ & 0,400 \\
\hline $\mathbf{2}$ & 0,320 \\
\hline 3 & 0,213 \\
\hline $\mathbf{4}$ & 0,160 \\
\hline $\mathbf{5}$ & 0,128 \\
\hline $\mathbf{6}$ & 0,107 \\
\hline $\mathbf{7}$ & 0,091 \\
\hline $\mathbf{8}$ & 0,080 \\
\hline $\mathbf{9}$ & 0,071 \\
\hline $\mathbf{1 0}$ & 0,064 \\
\hline $\mathbf{1 1}$ & 0,058 \\
\hline $\mathbf{1 2}$ & 0,053 \\
\hline & \\
\hline
\end{tabular}

\section{RESPON SPEKTRUM}

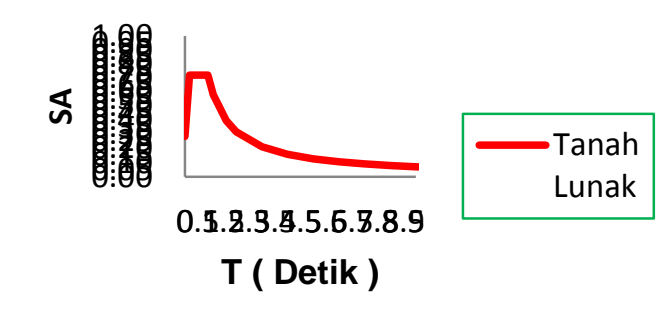

Gambar 26 : Kurva Respons Spektra

(Hasil Perhitungan)

\section{Perhitungan Berat Bangunan}

Perhitungan berat bangunan adalah langkah dalam menentukan gaya gempa, dalam hal ini perhitungan ini bertujuan untuk mengetahui seberapa besar gaya lateral equivalen yang akan diterima oleh portal, terdapat berbagai macam beban yang dipikul oleh bangunan seperti beban pelat, beban keramik, beban tembok, beban balok \& kolom dan beban lainnya, maka dari itu guna memperoleh beban yang mendekati keasliannya pada lapangan maka dilakukan proses perhitungan berat bangunan pada lantai atap, lantai 2 dan lantai 1 sebagai berikut : Analisis Beban Gempa Statik Ekivalen.

Perhitungan pembebanan : beban yang dipikul oleh struktur dihitung menurut pedoman perencanaan pembebanan untuk rumah dan gedung 1987.

Untuk lantai 1 \& 2 :

Beban mati $\left(Q_{D}\right)$

Plat beton $(\mathrm{t}=10.5 \mathrm{~cm})=0,105 \times 24$

$$
=2,52 \mathrm{KN}
$$

Spesi $(\mathrm{t}=2 \mathrm{~cm})=2 \times 0,21$

$$
=0,42 \mathrm{KN}
$$

$\operatorname{Keramik}(\mathrm{t}=1 \mathrm{~cm})$

$$
=1 \times 0,24=0,24 \mathrm{KN}
$$

Plafond dan penggantung

$=18 \mathrm{KN}$

Beban hidup $\left(Q_{L}\right)=2,50 \mathrm{KN}$

Untuk lantai atap

Beban mati $\left(Q_{D}\right)$

Plat beton $(\mathrm{t}=10.5 \mathrm{~cm})=0,105 \times 24$

$$
=2,52 \mathrm{KN}
$$

Plafond dan penggantung

$$
=18 \mathrm{KN}
$$

Beban hidup ( $\left.Q_{L}\right)$

$=2,50 \mathrm{KN}$ (Asumsi Lantai Atap Akan

Menjadi lantai Biasa )

Ukuran Bangunan :

Lebar bangunan ( ly ) $=13 \mathrm{~m}$

Panjang bangunan $(\mathrm{Ix}) \quad=6,9 \mathrm{~m}$

Tinggi bangunan $(\mathrm{H}) \quad=11,06 \mathrm{~m}$

\section{a. LANTAI 1}

Beban mati $\left(W_{D}\right)$

- $\operatorname{Keramik}(\mathrm{t}=1 \mathrm{~cm})=1 \times 0,24 \mathrm{x}$ $13 \times 36,9=115,13 \mathrm{KN}$

- Spesi $(\mathrm{t}=2 \mathrm{~cm})=2 \times 0,21 \times 13$ $x 36,9=201,47 \mathrm{KN}$

- Plat beton $(\mathrm{t}=10.5 \mathrm{~cm})$

$$
=0,105 \times 24 \times 13 \times 36,9
$$

$=1.208,84 \mathrm{KN}$

- Plat bondek=0,074x13x 36,9

$$
=35,50 \mathrm{KN}
$$

- Plafond $=0,18 \times 13 \times 36,9$

$$
=86,35 \mathrm{KN}
$$

- Instalasi Air dan Listrik $=0,25 \times 13 \times 36,9=119,93 \mathrm{KN}$

- Balok(WF.500.200.10.16) $=78 \times 0,897=69,97 \mathrm{KN}$ 
- Balok(WF.400.200.8.13) $=110,7 \times 0,66=73,06 \mathrm{KN}$

- Kolom( HB.350.357.19.19)

$=(1,75+1,89) \times 18 \times 1,56$

$=102,21 \mathrm{KN}$

- Pasangan dinding $1 / 2$ bata

$=(1,75+1,89) \times 2 \times(13+36,9)$

$\times 2,5=\underline{908,18 \mathrm{KN}}$

$W_{D}=2.920,63 \mathrm{KN}$

Beban hidup $\left(\mathrm{W}_{\mathrm{L}}\right)$

$W_{\mathrm{L}}=2,5 \times 13 \times 36,9=1199,25 \mathrm{KN}$

Koefisien reduksi untuk peninjauan gempa $=0,3$ maka :

$\mathrm{W}_{\mathrm{L}}=0,3 \times 1199,25=359,775 \mathrm{KN}$

Berat total lantai 2 :

$W_{(1)}=2920,63+359,775$

$=3280,409 \mathrm{KN}$

\section{b. LANTAI 2}

Beban mati $\left(W_{D}\right)$

- $\operatorname{Keramik}(\mathrm{t}=1 \mathrm{~cm})=1 \times 0,24 \mathrm{x}$ $13 \times 36,9=115,13 \mathrm{KN}$

- $\quad$ Spesi $(\mathrm{t}=2 \mathrm{~cm})=2 \times 0,21 \times 13$ $x 36,9=201,47 \mathrm{KN}$

- Plat beton $(\mathrm{t}=10.5 \mathrm{~cm})$

$$
=0,105 \times 24 \times 13 \times 36,9
$$$$
=1.208,84 \mathrm{KN}
$$

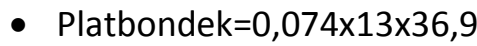
$=35,50 \mathrm{KN}$

- Plafond $=0,18 \times 13 \times 36,9$ $=86,35 \mathrm{KN}$

- Instalasi Air dan

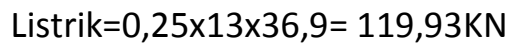

- Balok(WF.500.200.10.16) $=78 \times 0,897=69,97 \mathrm{KN}$

- Balok(WF.400.200.8.13) $=110,7 \times 0,66=73,06 \mathrm{KN}$

- $\operatorname{Kolom}($ HB.350.357.19.19)

$=(1,89+1,89) \times 18 \times 1,56$

$=102,21 \mathrm{KN}$

- Pasangan dinding $1 / 2$ bata $=(1,75+1,89) \times 2 \times(13+$ $36,9) \times 2,5=943,11 \mathrm{KN}$ $\mathrm{W}_{\mathrm{D}}=2.959,50 \mathrm{KN}$ Beban hidup $\left(\mathrm{W}_{\mathrm{L}}\right)$ $W_{L}=2,5 \times 13 \times 36,9$ $=1199,25 \mathrm{KN}$
Koefisien reduksi untuk peninjauan gempa $=0,3$ maka :

$\mathrm{W}_{\mathrm{L}}=0,3 \times 1199,25$ $=359,775 \mathrm{KN}$

Berat total lantai 2 : $W_{(2)}=2959,50+359,775$ $=3319,27 \mathrm{KN}$

\section{c. LANTAI ATAP}

Beban mati $\left(W_{D}\right)$

- Plat beton $(\mathrm{t}=10.5 \mathrm{~cm})$ $=0,105 \times 24 \times 13 \times 36,9$ $=1.208,84 \mathrm{KN}$

- Plat bondek=0,074x13x 36,9 $=35,50 \mathrm{KN}$

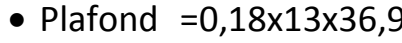
$=86,35 \mathrm{KN}$

- Instalasi Air dan

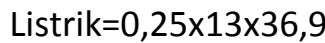
$=119,93 \mathrm{KN}$

- Balok(WF.500.200.10.16) $=78 \times 0,897=69,97 \mathrm{KN}$

- Balok(WF.400.200.8.13) $=110,7 \times 0,66=73,06 \mathrm{KN}$

- Kolom ( HB.350.357.19.19) $=1,89 \times 18 \times 1,56=53,07 \mathrm{KN}$

Pasangan dinding $1 / 2$ bata $=1,89 \times 2 \times(13+36,9) \times 2,5$ $=\underline{471,56 \mathrm{KN}}$

$$
\mathrm{W}_{\mathrm{D}}=2.118,27 \mathrm{KN}
$$

Asumsi Beban hidup antara lantai 1\&2 dianggap sama dengan lantai atap dengan asumsi lantap atap akan dijadikan lantai 3:

$W_{L}=2,5 \times 13 \times 36,9=1199,25 \mathrm{KN}$ Koefisien reduksi untuk peninjauan gempa $=0,3$ maka :

$$
W_{L}=0,3 \times 1199,25=359,775 \mathrm{KN}
$$

Berat total lantai Atap :

$$
\begin{aligned}
\mathrm{W}_{\text {(Atap) }} & =2118,27+359,775 \\
& =2478,04 \mathrm{KN}
\end{aligned}
$$

berat total keseluruhan lantai :

$\mathrm{W}_{\text {TOTAL }}=3280,41+3319,27+2478,04$

$$
=9.077,72 \mathrm{KN}
$$

\section{Perhitungan Koefisen Respons Seismik} (Cs) Dan Base Shear (V)

Dalam menentukan Geser dasar seismik dibutuhkan beberapa item 
perhitungan antara lain koefisien respons seismik $\left(C_{S}\right)$ dan berat seismik efektif ( $W_{T}$ ) yang dimana berat seismik efektif telah ditentukan dari Kombinasi beban $W_{D}$ dan $W_{L}$ yang direduksi (dalam hal ini koefisien reduksi untuk rumah sakit : 0,3 ), perhitungan berdasarkan persamaan (2.21) :

$\mathrm{T}=\mathrm{Ct} . \mathrm{h}_{\mathrm{n}}{ }^{\mathrm{x}} \quad$ (SNI-1726-2012, pasal 7.8.2.1)

$$
\begin{aligned}
\mathrm{T} & =0,0724 \times 11,06^{0,80} \\
& =0,495 \\
\mathrm{Ts} & =0,889 \\
\mathrm{Sa} & =\mathrm{S}_{\mathrm{DS}} \\
& =0,720 \\
\mathrm{Cs} & =\frac{\mathrm{S}_{\mathrm{a}} \cdot \mathrm{l}_{\mathrm{e}}}{\mathrm{R}}
\end{aligned}
$$

(SNI-1726-2012, pasal 7.8.1.1)

$$
\begin{aligned}
& =\frac{0,720 \cdot 1,5}{8} \\
& =0,135
\end{aligned}
$$

Cs $\min =0,044 S_{D S} \cdot l_{e}$

(SNI-1726-2012, pasal7.8.1.1)

$$
\begin{aligned}
& =0,044 \times 0,720 \times 1,5 \\
& =0,048
\end{aligned}
$$

Cs min >0,010kk! (SNI-

1726-2012, pasal 7.8.1.1)

$$
\begin{aligned}
& \mathrm{V}=\mathrm{Cs} . \mathrm{Wt} \\
& =0,135 \times 9077,7=1225,5
\end{aligned}
$$

Perhitungan Gaya Lateral Equivalen (F)

Langkah terakhir dari perhitungan beban gempa adalah menentukan besaran gaya lateral equivalen yang bekerja. Dalam hal ini gaya lateral equivalen diartikan sebagai gaya yang bekerja horizontal pada joint (simpul) sebagai akumulasi dari seluruh beban struktur antara beban hidup maupun beban mati, berikut ini adalah cara perhitungan gaya lateral equivalen berdasarkan SK-SNI 1726:2012 tentang "Tata cara perencanaan ketahanan gempa untuk struktur bangunan gedung dan non gedung ", perhitungan berdasarkan persamaan (2.22):

$$
\begin{aligned}
& \mathrm{Fx}=\mathrm{V} \frac{\mathrm{w}_{\mathrm{x}} \cdot \mathrm{h}_{\mathrm{x}}^{\mathrm{k}}}{\sum_{1=1}^{\mathrm{n}} \mathrm{w}_{\mathrm{i}} \cdot \mathrm{h}_{\mathrm{x}}^{\mathrm{k}}} \quad(\mathrm{SNI}- \\
&1726-2012, \text { pasal } 7.8 .1) \\
&=1225,5 \frac{2478 \times 11,06^{1,0}}{63053}
\end{aligned}
$$

$$
=533 \mathrm{KN}
$$

Dari contoh perhitungan diatas, guna mempersingkat hitungan dan memudahkan proses pembacaan maka hasil perhitungan pada lantai-lantai selanjutnya dilakukan proses rekapitulasi beban gempa yang bekerja, hasil rekapitulasi beban dicantumkan pada tabel dibawah ini :

\section{Tabel 8 : Gaya Lateral Ekivalen Arah} Sumbu $Y$

\begin{tabular}{|c|c|c|c|c|c|}
\hline Lantai & $\mathbf{h}$ & $\mathbf{W}$ & $\mathbf{W . h}^{\mathbf{k}}$ & $\mathbf{F}$ lateral & $\mathbf{F}_{\mathbf{y}} / \mathbf{N}$ \\
\hline 3 & 11,06 & 2478,04 & 27407,1 & 533 & 178 \\
\hline 2 & 7,28 & 3319,27 & 24164,3 & 470 & 157 \\
\hline 1 & 3,5 & 3280,41 & 11481,4 & 223 & 74 \\
\hline$\Sigma$ & & 9077,72 & 63052,9 & & \\
\hline
\end{tabular}

Tabel 9 : Gaya Lateral Ekivalen Arah Sumbu X

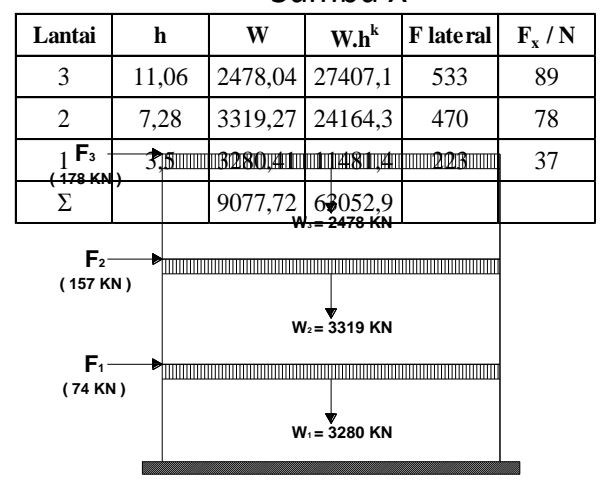

Gambar 27 : Distribusi Beban Gempa Arah Sumbu YPada Struktur Bangunan ( Hasil Perhitungan ) 


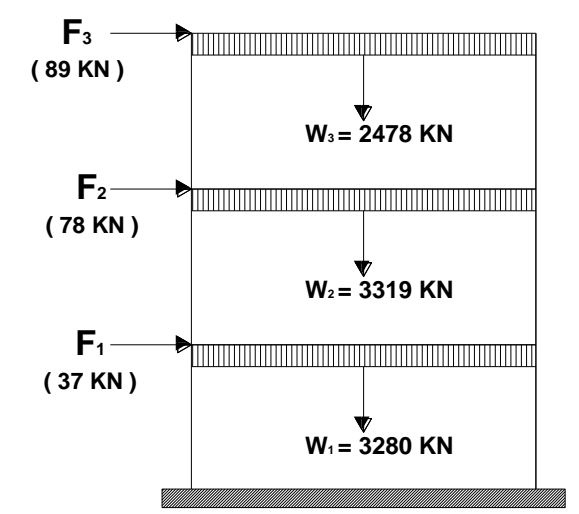

Gambar 28 : Distribusi Beban Gempa

Arah Sumbu X Pada Struktur

Bangunan ( Hasil Perhitungan )

\section{PERHITUNGAN BALOK}

Langkah selanjutnya yaitu perhitungan balok, dalam hal ini beberapa hal yang diperlukan adalah data-data profil yang diperoleh dari tabel baja serta data-data perhitungan $M_{\max }$ dan Gaya dalam lainnya, berikut perhitungannya :

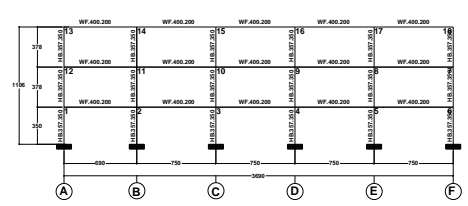

Gambar 29 :Struktur Portal Gedung

( Data Existing )Profil Terpasang

( Batang 1-2) :

\section{Data Analisis :}

Batang:BATANG 1-2

Profil :WF $400 \times 200 \times 8 \times 13$

Dalam menentukan Data-data Profil maka digunakan tabel profil baja (Dalam skripsi ini digunakan Tabel Profil Konstruksi Bajalr. Rudy Gunawan), melalui pembacaan tabel profil diketahui data profil sebagai berikut:
- $\mathrm{Ag}=8412 \mathrm{~mm}^{2}$
- $\mathrm{h}=400 \mathrm{~mm}$
- $\mathrm{Ix}=237000000 \mathrm{~mm}^{4}$
- $b=200 \mathrm{~mm}$
- $\mathrm{ly}=17400000 \mathrm{~mm}^{4}$
- $\mathrm{tw}=8 \mathrm{~mm}$

- $\mathrm{S} x=1190000 \mathrm{~mm}^{3}$

- $\mathrm{tf}=13 \mathrm{~mm}$

- $S y=174000 \mathrm{~mm}^{3}$

- $r x=168 \mathrm{~mm}$

- $r y=55,4 \mathrm{~mm}$

- $r=16 \mathrm{~mm}$

Dalam menganalisa keamanaan profil baja yang digunakan maka langkah sebelumnya yaitu menentukan gaya-gaya yang bekerja pada portal, gaya tersebut dihitung berdasarkan perhitungan beban gravitasi yang bekerja pada portal ( beban mati, beban hidup dan beban gempa),perhitungan statika dilakukan dengan menggunakan metode Takabeya, Analisa Gaya dalam tersebut meliputi perhitungan gaya momen, lintang dan gaya normal, dari perhitungan statika yang telah dilakukan sebelumnya maka diperoleh gaya dalam sebagai berikut (Hitungan Struktur terdapat pada bagian lampiran-lampiran) :

- $\mathrm{M}_{\mathrm{u}}=96,55 \mathrm{KN} . \mathrm{m}$

- $\mathrm{V}_{\mathrm{u}}=164,29 \mathrm{KN} \cdot \mathrm{m}$

- $\mathrm{q}_{\mathrm{L}}=11,17 \mathrm{KN}$

Material Baja ( Berdasarkan Data Perencanaan ):

Material=BJ -41

fy $=250 \mathrm{Mpa}$

$\mathrm{E}=200000 \mathrm{Mpa}$

$\mathrm{G}=80000 \mathrm{MPa}$

$\mathrm{fr}=75 \mathrm{MPa}$

$\mathrm{L}=6,9 \mathrm{~m}$

Panjang bentang, $L x \quad=6,9 \mathrm{~m}$

Jarak antar sokongan lateral, Ly1,2 m

Perhitungan Centre of Gravity

Nilai dari Centre of Gravity pada baja profil setengah I dapat dihitung dengan persamaan (2.27), berikut perhitungannya:

$\mathrm{Cx}=$

$$
\begin{aligned}
& \frac{\left(B . t-\frac{\mathrm{t}}{2}\right)+\left(\frac{\mathrm{d}}{2}-\mathrm{t}\right) \mathrm{t} w\left[\left(\frac{\mathrm{d}}{2}-\mathrm{t}\right)+\right]+\left(2\left(1-\frac{\pi}{2}\right) \mathrm{r}^{2}(0.2234 . r+\mathrm{t})\right)}{(B . t)+\left[\left(\frac{d}{2}-\mathrm{t}\right) \mathrm{tw}\right]+\left(2\left(1-\frac{\pi}{4}\right) r^{2}\right)} \\
& =42,33 \mathrm{~mm} \\
& \mathrm{Zx}=0,5 \cdot \mathrm{A} \text {. a } \\
& =0,5 \times 8412 \times(400-2 \times 42,33)
\end{aligned}
$$


$=1326299$

\section{Cek Zx terhadap Sx}

Berdasarkan SK SNI 03 - 1729 - 2002 tentang "Tata Cara Perencanaan Struktur Baja Untuk Bangunan Gedung" Disebutkan bahwa Kuat lentur plastis Mp momen lentur yang menyebabkan seluruh penampang mengalami tegangan leleh harus diambil yang lebih kecil dari Z fy atau 1,5 My, dan Z adalah modulus penampang plastis, berdasarkan persamaan (2.26), berikut perhitungannya :

$$
\begin{aligned}
& \frac{z_{x}}{S_{x}}= \frac{1326299}{1190000} \\
&=1,115<1,5 \\
& \\
&(\ldots \text { OKK })
\end{aligned}
$$

\section{Cek kekompakan profil}

Dalam langkah perhitungan struktur profil baja langkah awal yaitu menentukan rasio batas kekompakan guna mengetahui profil tersebut telah kompak, tidak kompak ataupun langsing, kekompakan dibutuhkan sebagai informasi awal terhadap perlakuan cara perhitungan profil tersebut, berdasarkan persamaan (2.28) sampai dengan (2.29), berikut perhitungannya:

$$
\begin{aligned}
\lambda & =\frac{b}{2 \cdot t_{f}} \\
\lambda & =\frac{200}{2 \cdot 13} \\
& =7,692 \\
\lambda_{p} & =\frac{170}{\sqrt{f_{y}}} \\
\lambda_{p} & =\frac{170}{\sqrt{250}} \\
& =10,752 \\
\lambda_{r} & =\frac{370}{\sqrt{f_{y}}-f_{r}} \\
\lambda_{r} & =\frac{370}{\sqrt{250}-75} \\
& =27,969 \\
\lambda & <\lambda p \text { (Profil Kompak) }
\end{aligned}
$$

Cek kapasitas berdasarkan Flange Local Buckling
Salah satu parameter untuk mengetahui keamanan suatu profil yang akan dipakai yaitu mengecek kapasitas profil terhadap tekuk lokal pada sayap (Flange Local Buckling)berdasarkan persamaan (2.30), berikut perhitungannya :

$$
\begin{aligned}
& M_{n} \quad=M_{p} \\
& =250 \times 1326299 \times 10^{6} \\
& =331,575 \mathrm{KN} . \mathrm{m} \\
& \varnothing M_{n} \quad=0,9 \times 331,57 \\
& =298,417 \mathrm{KN} . \mathrm{m}
\end{aligned}
$$

Sehingga kuat rencana berdasarkan FLB $\varnothing \mathrm{M}_{\mathrm{n}}$ :

298,417KN.m>96,549KN.m(..OKK)

\section{Cek kapasitas berdasarkan Local Torsional Buckling}

Salah satu parameter untuk mengetahui keamanan suatu profil yang akan dipakai yaitu mengecek kapasitas profil terhadap tekuk torsi lokal (Local Torsional Buckling), berdasarkan tabel (2.12), berikut perhitungannya :

$$
\begin{aligned}
\mathrm{L}_{\mathrm{p}} & =1,76 \cdot \mathrm{r}_{\mathrm{y}} \cdot \sqrt{\frac{\mathrm{E}}{\mathrm{f}_{\mathrm{y}}}} \\
& =2757,83 \mathrm{~mm} \\
\mathrm{~F}_{\mathrm{I}} & =175 \mathrm{Mpa} \\
\mathrm{I}_{\mathrm{w}} & =\frac{\mathrm{I}_{\mathrm{y}}}{2} \cdot \frac{\mathrm{h}^{2}}{2} \\
& =6,08461 \mathrm{E}+11 \\
& =0,608 \times 10^{12} \\
\mathrm{~J} & =\frac{2 \cdot\left(\mathrm{B} \cdot \mathrm{t}^{3}\right)}{3} \\
& =292933,33 \mathrm{~mm}^{4} \\
\mathrm{X}_{1} & =\frac{\pi}{S_{\mathrm{x}}} \cdot \sqrt{\frac{\mathrm{EGJA}}{2}} \\
& =11721,466 \\
\mathrm{X}_{2} & =4 \cdot\left(\frac{\mathrm{S}_{\mathrm{x}}}{\mathrm{GJ}}\right)^{2} \cdot \frac{\mathrm{I}_{\mathrm{w}}}{\mathrm{I}_{\mathrm{y}}} \\
& =0,00036067 \\
\mathrm{~L}_{\mathrm{r}} & =\mathrm{r}_{\mathrm{y}} \frac{\mathrm{X}_{1}}{\mathrm{f}_{1}} \cdot \sqrt{1+\sqrt{1+\mathrm{X}_{2} \cdot \mathrm{f}_{1}^{2}}} \\
& =7845,8759 \mathrm{~mm} \\
\mathrm{~L} & =6900 \mathrm{~mm} \\
\mathrm{~L}_{\mathrm{p}} & <\mathrm{L} \quad<\mathrm{L}_{\mathrm{r}}
\end{aligned}
$$

Maka Balok merupakan bentang menengah. 


\section{Kuat Lentur Nominal pada kondisi Local Torsional Buckling}

Salah satu parameter untuk mengetahui keamanan suatu profil yang akan dipakai yaitu mengecek kapasitas profil terhadap tekuk torsi lokal (Local Torsional Buckling) yang dipengaruhi oleh gaya Momen yang bekerja berdasarkan persamaan (2.38), berikut perhitungannya :

$$
M_{n}=C_{b} \cdot\left[M_{r}+\left(M_{p}-M_{r}\right) \frac{L_{r}-L}{L_{r}-L_{p}}\right] \leq 1,00
$$

Simple beam

$$
\begin{aligned}
& \mathrm{Cb}=1,14 \\
& M_{r}=\left(f_{y}-f_{r}\right) \cdot S_{x} \\
& =208,25 \mathrm{KN} . \mathrm{m} \\
& M_{n}=263,541 \mathrm{KN} \cdot \mathrm{m}<\mathrm{M}_{\mathrm{p}} \\
& =331,57 \mathrm{KN} \cdot \mathrm{m} \\
& =237,187 \mathrm{KN} \cdot \mathrm{m}>\mathrm{M}_{p}=96,55 \mathrm{KN} \cdot \mathrm{m}
\end{aligned}
$$

Sehingga kuat lentur nominal

memenuhi (aman).

\section{Geser}

Salah satu parameter untuk mengetahui keamanan suatu profil yang akan dipakai yaitu mengecek kapasitas profil terhadap gaya geser yang bekerja, yaitu gaya yang bekerja tegak lurus terhadap bidang profil ( gaya lintang ) berdasarkan persamaan (2.42) sampai dengan (2.48), berikut perhitungannya :

Cek nilai banding $\mathrm{h}$ dan tw

$$
\begin{aligned}
& \frac{\mathrm{h}}{\mathrm{t}_{\mathrm{w}}}=\frac{374}{8}=46,75 \\
& \begin{aligned}
\mathrm{K}_{\mathrm{n}} & =5+\frac{5}{(\mathrm{a} / \mathrm{h})^{2}} \\
\mathrm{a} \quad & 1200 \mathrm{~mm} \\
& =5,49 \\
& =5,00
\end{aligned} \\
& \begin{aligned}
1,10 \sqrt{\frac{\mathrm{K}_{\mathrm{n}} \cdot \mathrm{E}}{\mathrm{f}_{\mathrm{y}}}}=69,603 \\
\frac{\mathrm{h}}{\mathrm{t}_{\mathrm{w}}}=46,75<1,10 \sqrt{\frac{\mathrm{K}_{\mathrm{n}} \cdot \mathrm{E}}{\mathrm{f}_{\mathrm{y}}}}=69,603 \\
\text { Maka: } \quad V_{n}=0,6 \cdot \mathrm{F}_{\mathrm{y}} \cdot \mathrm{A}_{\mathrm{w}} \\
=0,6 \times 250 \times 2992,0 \\
=448,800 \mathrm{KN}
\end{aligned}
\end{aligned}
$$

$$
\begin{array}{ll}
\varnothing V_{n} \quad=0,9 \times 448,800 \\
\varnothing V_{n} \quad=403,920 K N>V_{u}=164,293 \mathrm{KN} \\
& (\text { Aman })
\end{array}
$$

\section{Lendutan}

Salah satu parameter untuk mengetahui keamanan suatu profil yang akan dipakai yaitu mengecek kapasitas profil terhadap lendutan yang terjadi, Untuk memeriksa syarat lendutan, hanya beban hidup saja yang dipertimbangkan berdasarkan persamaan (2.49), berikut perhitungannya :

$$
\begin{aligned}
& \delta=\frac{5}{384} \cdot \frac{W L^{2}}{E . I} \\
& =\quad 6,95 \mathrm{~mm} \\
& \delta_{\text {maks }}=\frac{L}{240}=\frac{7500}{240}=28,750 \\
& \delta \text { maks }=28,750 \\
& \text { mm> }=6,95 \mathrm{~mm} \\
& (\text { Aman ) }
\end{aligned}
$$

\section{PERHITUNGAN KOLOM}

Langkah selanjutnya yaitu perhitungan kolom, dalam hal ini beberapa hal yang diperlukan adalah data-data profil yang diperoleh dari tabel baja serta data-data perhitungan $M_{\max }$ dan Gaya dalam lainnya, berikut detail portal dan perhitungannya :

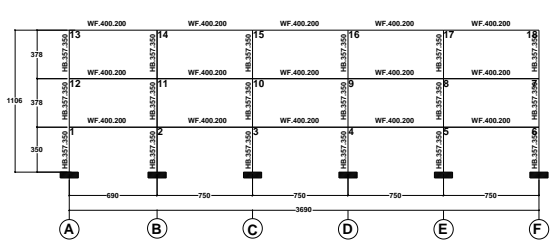

Gambar 30 :Struktur Portal Gedung ( Data Existing )

PROFIL TERPASANG ( BATANG 1-A ) :

Data analisis :

Batang:BATANG 1-A

\section{Profil :HB $350 \times 357 \times 19 \times 19$}

Dalam menentukan Data-data Profil maka digunakan tabel profil baja (Dalam skripsi ini digunakan Tabel Profil Konstruksi Bajalr. Rudy 
Gunawan), melalui pembacaan tabel profil diketahui data profil sebagai berikut:

- $A_{g}=19840 \mathrm{~mm}^{2}$

- $\mathrm{h}=350 \mathrm{~mm}$

- $\mathrm{I}_{\mathrm{x}}=428000000 \mathrm{~mm}^{4}$

- $\mathrm{b}=357 \mathrm{~mm}$

- $\mathrm{I}_{\mathrm{y}}=144000000 \mathrm{~mm}^{4}$

- $t_{\mathrm{w}}=19 \mathrm{~mm}$

- $S_{\mathrm{x}}=2450000 \mathrm{~mm}^{3}$

- $\mathrm{t}_{\mathrm{f}}=19 \mathrm{~mm}$

- Sy $=809000 \mathrm{~mm}^{3}$

- $r_{x}=147 \mathrm{~mm}$

- $r_{y}=85,3 \mathrm{~mm}$

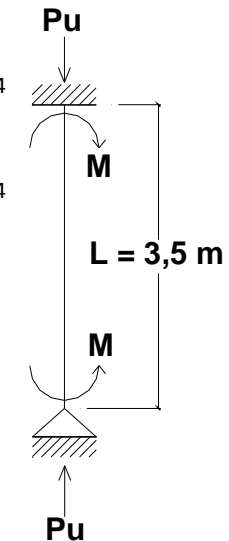

- $r=20 \mathrm{~mm}$

Gambar 31 : Balok-kolom ujung sendi -jepit (Data perhitungan)

Dalam menganalisa keamanaan profil baja yang digunakan maka langkah sebelumnya yaitu menentukan gaya-gaya yang bekerja pada portal, gaya tersebut dihitung berdasarkan perhitungan beban gravitasi yang bekerja pada portal ( beban mati, beban hidup dan beban gempa), perhitungan statika dilakukan dengan menggunakan metode Takabeya, Analisa Gaya dalam tersebut meliputi perhitungan gaya momen, lintang dan gaya normal ( Aksial ), dari perhitungan statika yang telah dilakukan sebelumnya maka diperoleh gaya dalam sebagai berikut (Hitungan Struktur terdapat pada bagian lampiran-lampiran) :

- $\mathrm{Pu} \quad=294,39 \mathrm{KN} \cdot \mathrm{m}$

- $\mathrm{Vu}=32,63 \mathrm{KN} . \mathrm{m}$

- $\mathrm{Mu}=138,59 \mathrm{KN}$

Material Baja ( Berdasarkan Data

Perencanaan ) :

Material=BJ -41

- $\mathrm{f}_{\mathrm{y}} \quad=250 \mathrm{MPa}$

- $\mathrm{E} \quad=200000 \mathrm{MPa}$

- $\mathrm{G}=80000 \mathrm{MPa}$
- $\mathrm{f}_{\mathrm{r}}=75 \mathrm{MPa}$

$\mathrm{L}=3,5 \mathrm{~m}$

$\mathrm{k}_{\mathrm{c}}=0,8$ ( Tumpuan Jepit-Sendi )

Panjang bentang, $L=3,5 \mathrm{~m}$

\section{Perhitungan Centre of Gravity:}

Nilai dari Centre of Gravity pada baja profil setengah I dapat dihitung dengan persamaan (2.27) sebagai berikut :

$\mathrm{Cx}=$

$$
\begin{aligned}
& \frac{\left(B \cdot t \cdot \frac{t}{2}\right)+\left(\frac{d}{2}-t\right) t_{w}\left[\left(\frac{d}{2}-t\right)+\right]+\left(2\left(1-\frac{\pi}{4}\right) r^{2}(0.2234 \cdot r+t)\right)}{(B . t)+\left[\left(\frac{d}{2}-t\right) t w\right]+\left(2\left(1-\frac{\pi}{4}\right) r^{2}\right)} \\
& C_{x}=35,89 m m \\
& Z x=0,5 \cdot A \cdot a \\
& =0,5 \times 19840 \times(350-2 \times 35,89) \\
& =2759954,3
\end{aligned}
$$

\section{Cek Zx terhadap Sx}

Berdasarkan SK SNI 03 - 1729 - 2002 tentang "Tata Cara Perencanaan Struktur Baja Untuk Bangunan Gedung" Disebutkan bahwa Kuat lentur plastis $\mathrm{Mp}$ momen lentur yang menyebabkan seluruh penampang mengalami tegangan leleh harus diambil yang lebih kecil dari $Z$ fy atau 1,5 My, dan $\mathrm{Z}$ adalah modulus penampang plastis, berdasarkan persamaan (2.26), berikut perhitungannya

$\frac{\vdots}{Z_{x}}=\frac{2759954}{2450000}$

$Z x=1,127<1,5(\ldots \ldots .0 k k)$

\section{Cek kekompakan profil}

Langkah pertama dalam perhitungan pada profil baja yaitu menentukan batas kekompakan profil tersebut, perhitungannya meliputi batas kelangsingan pada Sayap (Flange) dan pada badan (Web) profil tersebutberdasarkan persamaan (2.28), (2.30) dan persamaan (2.56) Sampai dengan persamaan (2.60), berikut perhitungannya:

Sayap (Flange)

$\lambda=\frac{b}{2 \cdot t_{f}}$

$\lambda=\frac{357}{2.19}$ 


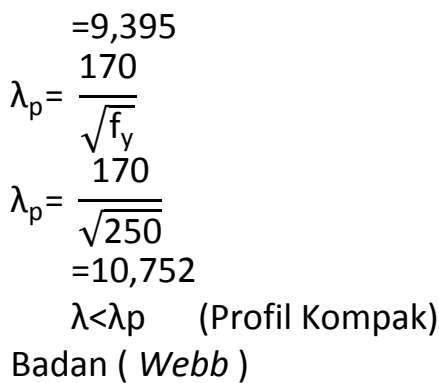

$\frac{\mathrm{N}_{\mathrm{u}}}{\emptyset \mathrm{bN}_{\mathrm{y}}}=\frac{294,386 \cdot 10^{3}}{0,9 \cdot 19840 \cdot 250}$

$\begin{aligned} & =0,0659<0,125 \\ \lambda_{p} & =\frac{500}{f_{y}} \cdot\left(2,33-\frac{N_{u}}{\phi b N_{y}}\right)\end{aligned}$

$\lambda p \quad=71,596$

$\frac{665}{\sqrt{f_{y}}}=\frac{665}{\sqrt{250}}$

$=42,058$

$\lambda p=71,596>42,058$

$\lambda=\frac{\mathrm{h}}{\mathrm{t}_{\mathrm{w}}}$

$\lambda=\frac{312}{19}$

$=16,421$

$\lambda<\lambda p \quad$ (Profil Kompak)

Maka Profil tersebut kompak

Cek kapasitas berdasarkan Flange Local Buckling

Salah satu parameter untuk mengetahui keamanan suatu profil yang akan dipakai yaitu mengecek kapasitas profil terhadap tekuk lokal pada sayap (Flange Local Buckling), berdasarkan persamaan (2.39), berikut perhitungannya :

$\mathrm{Mn}=\mathrm{Mp}$

$=250 \times 2759954 \times 10^{6}$ $=689,989 \mathrm{KN} . \mathrm{m}$

$\varnothing M_{n}=0,9 \times 689,989$ $=620,990 \mathrm{KN} . \mathrm{m}$

Sehingga kuat rencana berdasarkan $F L B \varnothing \mathrm{Mn}$ :

$620,990 \mathrm{KN} . \mathrm{m}>138,585 \mathrm{KN} . \mathrm{m}$

(.....OKK)

Cek kapasitas berdasarkan Local Torsional Buckling
Salah satu parameter untuk mengetahui keamanan suatu profil yang akan dipakai yaitu mengecek kapasitas profil terhadap tekuk torsi lokal (Local Torsional Buckling), berdasarkan persamaan pada tabel (2.12), berikut perhitungannya :

$$
\begin{aligned}
& \mathrm{L}_{\mathrm{p}}=1,76 \cdot \mathrm{r}_{\mathrm{y}} \cdot \sqrt{\frac{\mathrm{E}}{\mathrm{f}_{\mathrm{y}}}} \\
& \begin{aligned}
=4246,3 \mathrm{~mm} \\
\mathrm{~F}_{\mathrm{I}} \quad=175 \mathrm{Mpa}
\end{aligned} \\
& \begin{aligned}
\mathrm{I}_{\mathrm{W}} & =\frac{\mathrm{I}_{\mathrm{y}}}{2} \cdot \frac{\mathrm{h}^{2}}{2} \\
& =3,50438 \mathrm{E}+12 \\
& =3,504 \times 10^{12}
\end{aligned} \\
& \begin{aligned}
\mathrm{J}= & \frac{2 \cdot\left(\mathrm{B} \cdot \mathrm{t}^{3}\right)}{3} \\
& =1632442 \mathrm{~mm}^{4}
\end{aligned} \\
& \mathrm{X}_{1}=\frac{\pi}{\mathrm{S}_{\mathrm{x}}} \cdot \sqrt{\frac{\mathrm{EGJA}}{2}} \\
& =20640,418 \\
& \mathrm{X}_{2}=4 \cdot\left(\frac{\mathrm{S}_{\mathrm{x}}}{\mathrm{GJ}}\right)^{2} \cdot \frac{\mathrm{I}_{\mathrm{W}}}{\mathrm{I}_{\mathrm{y}}} \\
& \quad=3,4260 \mathrm{E}-05 \\
& \mathrm{~L}_{\mathrm{r}}=\mathrm{r}_{\mathrm{y}} \frac{\mathrm{X}_{1}}{\mathrm{f}_{1}} \cdot \sqrt{1+\sqrt{1+X_{2} \cdot \mathrm{f}_{1}^{2}}} \\
& =15688,0 \mathrm{~mm} \\
& \mathrm{~L}=3500 \mathrm{~mm} \\
& \mathrm{~L}
\end{aligned}
$$

Karena $L<L_{p}$ Maka Kolom tergolong bentang pendek

\section{Kuat Lentur Nominal pada kondisi Local Torsional Buckling}

Salah satu parameter untuk mengetahui keamanan suatu profil yang akan dipakai yaitu mengecek kapasitas profil terhadap tekuk torsi lokal (Local Torsional Buckling) yang dipengaruhi oleh gaya Momen yang bekerja,berdasarkan persamaan (2.39), berikut perhitungannya :

Karena tergolong bentang pendek maka :

$$
\begin{aligned}
\text { Dipakai: } & M n=M p \\
& =689,99 \mathrm{KN} . \mathrm{m} \\
\varnothing \mathrm{Mn} & =0,9 \times 689,989 \\
& =620,990 \mathrm{KN} . \mathrm{m}
\end{aligned}
$$

Faktor Pembesaran Momen 
Untuk memperoleh perhitungan

yang memenuhi standar keamanan, maka dilakukan proses pembesaran momen sesuai dengan pasal-pasal yang terdapat pada SNI 1726:2002, tepatnya pada persaman (2.63) sampai dengan persamaan (2.65 ), berikut perhitungannya :

$$
\begin{aligned}
& \frac{k_{x} \cdot L}{r_{x}}=\frac{0,80 \cdot 3500}{147}=19,048 \\
& N_{c r}=\frac{\pi^{2} \cdot E \cdot A_{g}}{\left(\frac{k L}{r}\right)^{2}} \\
& N_{c r} \quad=107941,889 K N \\
& C_{m}=0,6-0,4 \cdot \frac{M_{1}}{M_{2}} \\
& C m=1,00 \\
& \delta \quad=\frac{C_{m}}{1-\frac{N_{u}}{N_{c r}}} \\
& \delta \quad=1,003>1,0
\end{aligned}
$$

\section{Momen Maksimum Terfaktor}

Untuk memperoleh perhitungan yang memenuhi standar keamanan, maka dilakukan proses pemfaktoran momen maksium sesuai dengan pasalpasal yang terdapat pada SNI 1726:2002, tepatnya pada persamaan (2.61), berikut perhitungannya :

$$
\begin{aligned}
M_{\text {ntu }} & =138,59 K N \cdot m+\delta s M_{\text {ltu }}=0 \\
M_{u} & =\delta b M_{\text {ntu }}+\delta s M_{\text {ltu }} \\
& =138,96+0 \\
& =138,96
\end{aligned}
$$

Menentukan Parameter Kelangsingan

Untuk memperoleh perhitungan yang memenuhi standar keamanan, perlu dilakukan proses penentuan parameter kelangsingan profil sesuai dengan pasal-pasal yang terdapat pada SNI 1726:2002, tepatnya pada persamaan (2.53) berikut perhitungannya :

$$
\begin{aligned}
& \lambda_{c}=\frac{1}{\pi} \cdot \frac{L_{k}}{r_{y}} \cdot \sqrt{\frac{f_{y}}{E}} \\
& \lambda c=0,462 \\
& \omega \quad=\frac{1,43}{1,6-0,67 \cdot \lambda_{c}} \\
& \omega \quad=1,108
\end{aligned}
$$

Menentukan $\mathrm{Nu} / \varnothing \mathrm{Nn}$
Untuk mengetahui tingkat keamanan, perlu dilakukan proses penentuan rasio antara beban aksial maksimum profil, dengan berdasarkan persamaan ( 2.51 ) dan persamaan ( 2.54 ) berikut perhitungannya :

$$
\begin{aligned}
\mathrm{N}_{\mathrm{n}} & =\mathrm{A}_{\mathrm{g}} \cdot \frac{\mathrm{f}_{\mathrm{y}}}{\omega} \\
\mathrm{N}_{\mathrm{n}} & =4476,54 \mathrm{KN} \\
\varnothing \mathrm{N}_{\mathrm{n}} & =0,85 \times 4476,54 \\
& =3805,06 \mathrm{KN} \\
\frac{\mathrm{N}_{\mathrm{u}}}{\emptyset \mathrm{N}_{\mathrm{n}}} & =\frac{294,39}{3805,06} \\
& =0,08<0,2
\end{aligned}
$$

\section{Interaksi aksial momen}

Berdasarkan rasio antara beban aksial maksimum profil, dengan mengacu padapasal yang terdapat pada SNI 1726:2002, tepatnya pada persamaan ( 2.54 ) dan ( 2.55 ) maka digunakan:

Karena $\frac{\mathrm{N}_{\mathrm{u}}}{\emptyset \mathrm{N}_{\mathrm{n}}}<0,2$, maka SNI

mensyaratkan :

$$
\begin{aligned}
& \frac{\mathrm{Nu}}{2 . \emptyset_{\mathrm{k}} \mathrm{Nn}}+\left(\frac{\mathrm{M}_{\mathrm{ux}}}{\emptyset \mathrm{Mnx}}+\frac{\mathrm{M}_{\mathrm{uy}}}{\emptyset \mathrm{Mny}}\right) \leq 1.0 \\
& 0,276<1,00 \quad \text { ( Profil Aman ) }
\end{aligned}
$$

\section{PERHITUNGAN KOLOM}

Langkah selanjutnya yaitu perhitungan kolom, dalam hal ini beberapa hal yang diperlukan adalah data-data profil yang diperoleh dari tabel baja serta data-data perhitungan

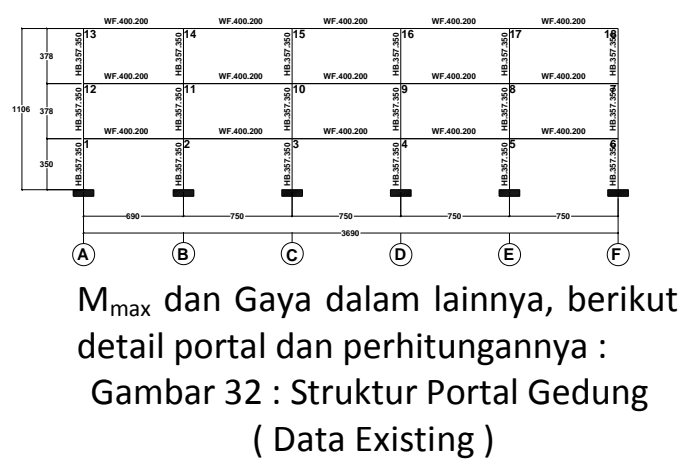

PROFIL TERPASANG ( BATANG 1-A ) : Data analisis :

Batang:BATANG 1-A

Profil :HB $350 \times 357 \times 19 \times 19$

Dalam menentukan Data-data Profil maka digunakan tabel profil baja (Dalam 
skripsi ini digunakan Tabel Profil Konstruksi Bajalr. Rudy Gunawan), melalui pembacaan tabel profil diketahui data profil sebagai berikut:

- $A_{g}=19840 \mathrm{~mm}^{2}$

- $\mathrm{H}=350 \mathrm{~mm}$

- $\mathrm{I}_{\mathrm{x}}=428000000 \mathrm{~mm}^{4}$

- $B=357 \mathrm{~mm}$

- $\mathrm{I}_{\mathrm{y}}=144000000 \mathrm{~mm}^{4}$

- $t_{\mathrm{w}}=19 \mathrm{~mm}$

- $\mathrm{S}_{\mathrm{x}}=2450000 \mathrm{~mm}^{3}$

- $\mathrm{t}_{\mathrm{f}}=19 \mathrm{~mm}$

- Sy $=809000 \mathrm{~mm}^{3}$

- $r_{x}=147 \mathrm{~mm}$

- $r_{y}=85,3 \mathrm{~mm}$

- $\mathrm{R}=20 \mathrm{~mm}$

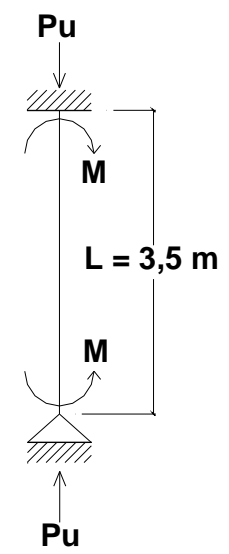

Gambar 33 : Balok-kolom ujung sendi -jepit (Data perhitungan)

Dalam menganalisa keamanaan profil baja yang digunakan maka langkah sebelumnya yaitu menentukan gayagaya yang bekerja pada portal, gaya tersebut dihitung berdasarkan perhitungan beban gravitasi yang bekerja pada portal ( beban mati, beban hidup dan beban gempa), perhitungan statika dilakukan dengan menggunakan metode Takabeya, Analisa Gaya dalam tersebut meliputi perhitungan gaya momen, lintang dan gaya normal ( Aksial ), dari perhitungan statika yang telah dilakukan sebelumnya maka diperoleh gaya dalam sebagai berikut (Hitungan Struktur terdapat pada bagian lampiranlampiran) :

- $\mathrm{Pu}=294,39 \mathrm{KN} \cdot \mathrm{m}$

- $\mathrm{Vu}=32,63 \mathrm{KN} \cdot \mathrm{m}$

- $\mathrm{Mu}=138,59 \mathrm{KN}$
Material Baja ( Berdasarkan Data

Perencanaan ):

Material=BJ -41

- $\mathrm{f}_{\mathrm{y}}=250 \mathrm{MPa}$

- $\mathrm{E} \quad=200000 \mathrm{MPa}$

- $\mathrm{G}=80000 \mathrm{MPa}$

- $\mathrm{f}_{\mathrm{r}}=75 \mathrm{MPa}$

$\mathrm{L}=3,5 \mathrm{~m}$

$\mathrm{k}_{\mathrm{c}}=0,8$ ( Tumpuan Jepit-Sendi )

Panjang bentang, $\mathrm{L}=3,5 \mathrm{~m}$

\section{Perhitungan Centre of Gravity:}

Nilai dari Centre of Gravity pada baja profil setengah I dapat dihitung dengan persamaan (2.27) sebagai berikut :

$\mathrm{Cx}=$

$\frac{\left(B . t \cdot \frac{t}{2}\right)+\left(\frac{d}{2}-t\right) t_{w}\left[\left(\frac{\frac{d}{2}-t}{2}\right)+\right]+\left(2\left(1-\frac{\pi}{4}\right) r^{2}(0.2234 . r+t)\right)}{(B . t)+\left[\left(\frac{d}{2}-t\right) t w\right]+\left(2\left(1-\frac{\pi}{4}\right) r^{2}\right)}$

$C_{x}=35,89 \mathrm{~mm}$

$\mathrm{Zx}=0,5 \cdot \mathrm{A}$. a

$=0,5 \times 19840 \times(350-2 \times 35,89)$

$=2759954,3$

\section{Cek Zx terhadap Sx}

Berdasarkan SK SNI 03 - 1729 2002 tentang "Tata Cara Perencanaan Struktur Baja Untuk Bangunan Gedung" Disebutkan bahwa Kuat lentur plastis $\mathrm{Mp}$ momen lentur yang menyebabkan seluruh penampang mengalami tegangan leleh harus diambil yang lebih kecil dari $Z$ fy atau 1,5 My , dan $Z$ adalah modulus penampang plastis, berdasarkan persamaan (2.26), berikut perhitungannya :

$\frac{Z_{x}}{S_{x}}=\frac{2759954}{2450000}$

$Z x=1,127<1,5 \quad$ (.......

\section{Cek kekompakan profil}

Langkah pertama dalam perhitungan pada profil baja yaitu menentukan batas kekompakan profil tersebut, perhitungannya meliputi batas kelangsingan pada Sayap ( Flange) dan pada badan (Web) profil tersebutberdasarkan persamaan 
(2.28), (2.30) dan persamaan (2.56) Sampai dengan persamaan (2.60), berikut perhitungannya:

Sayap ( Flange )

$\lambda=\frac{b}{2 \cdot t_{f}}$

$\lambda=\frac{357}{2.19}$

$=9,395$

$\lambda_{p}=\frac{170}{\sqrt{f_{y}}}$

$\lambda_{\mathrm{p}}=\frac{170}{\sqrt{250}}$

$=10,752$

$\lambda<\lambda p \quad$ (Profil Kompak)

Badan ( Webb)

$\frac{\mathrm{N}_{\mathrm{u}}}{3 \mathrm{bN}_{\mathrm{y}}}=\frac{294,386 \cdot 10^{3}}{0,9 \cdot 19840 \cdot 250}$

$=0,0659<0,125$

$\lambda_{p}=\frac{500}{f_{y}} \cdot\left(2,33-\frac{N_{u}}{2 b N_{y}}\right)$

$\lambda p \quad=71,596$

$\frac{665}{\sqrt{f_{y}}}=\frac{665}{\sqrt{250}}$

$=42,058$

$\lambda p \quad=71,596>42,058$

$\lambda=\frac{\mathrm{h}}{\mathrm{t}_{\mathrm{w}}}$

$\lambda=\frac{312}{19}$

$=16,421$

$\lambda<\lambda p \quad$ (Profil Kompak)

Maka Profil tersebut kompak.

\section{Cek kapasitas berdasarkan Flange} Local Buckling

Salah satu parameter untuk mengetahui keamanan suatu profil yang akan dipakai yaitu mengecek kapasitas profil terhadap tekuk lokal pada sayap (Flange Local Buckling), berdasarkan persamaan (2.39), berikut perhitungannya :

$\mathrm{Mn}=\mathrm{Mp}$

$$
\begin{gathered}
=250 \times 2759954 \times 10^{6} \\
=689,989 \mathrm{KN} . \mathrm{m}
\end{gathered}
$$

$\varnothing \mathrm{M}_{\mathrm{n}}=0,9 \times 689,989$

$=620,990 \mathrm{KN} . \mathrm{m}$

Sehingga kuat rencana berdasarkan $F L B \varnothing \mathrm{Mn}$ :

$620,990 K N . m>138,585 K N . m$ (.....OKK)

\section{Cek kapasitas berdasarkan Local} Torsional Buckling

Salah satu parameter untuk mengetahui keamanan suatu profil yang akan dipakai yaitu mengecek kapasitas profil terhadap tekuk torsi lokal (Local Torsional Buckling), berdasarkan persamaan pada tabel (2.12), berikut perhitungannya :

$L_{p}=1,76 \cdot r_{y} \cdot \sqrt{\frac{E}{f_{y}}}$

$=4246,3 \mathrm{~mm}$

$\mathrm{F}_{\mathrm{I}} \quad=175 \mathrm{Mpa}$

$I_{w}=\frac{I_{y}}{2} \cdot \frac{h^{2}}{2}$

$=3,50438 \mathrm{E}+12$

$=3,504 \times 10^{12}$

$\mathrm{J}=\frac{2 \cdot\left(\mathrm{B} \cdot \mathrm{t}^{3}\right)}{3}$

$=1632442 \mathrm{~mm}^{4}$

$\mathrm{X}_{1}=\frac{\pi}{\mathrm{s}_{\mathrm{x}}} \cdot \sqrt{\frac{\mathrm{EGJA}}{2}}$

$=20640,418$

$X_{2}=4 \cdot\left(\frac{S_{x}}{G J}\right)^{2} \cdot \frac{I_{w}}{I_{y}}$

$=3,4260 \mathrm{E}-05$

$L_{r}=r_{y} \frac{X_{1}}{f_{1}} \cdot \sqrt{1+\sqrt{1+X_{2} \cdot f_{1}^{2}}}$

$=15688,0 \mathrm{~mm}$

$\mathrm{L}=3500 \mathrm{~mm}$

$\mathrm{L}<\mathrm{L}_{\mathrm{p}}$

Karena $L<L_{p}$ Maka Kolom tergolong bentang pendek

Kuat Lentur Nominal pada kondisi Local Torsional Buckling

Salah satu parameter untuk mengetahui keamanan suatu profil yang akan dipakai yaitu mengecek kapasitas profil terhadap tekuk torsi lokal (Local Torsional Buckling) yang dipengaruhi oleh gaya Momen yang 
bekerja,berdasarkan persamaan

(2.39), berikut perhitungannya :

Karena tergolong bentang pendek maka :

Dipakai: $\mathrm{Mn}=\mathrm{Mp}=689,99 \mathrm{KN} . \mathrm{m}$

$$
\varnothing \mathrm{Mn}=0,9 \times 689,989
$$$$
=620,990 \mathrm{KN} \cdot \mathrm{m}
$$

\section{Faktor Pembesaran Momen}

Untuk memperoleh perhitungan yang memenuhi standar keamanan, maka dilakukan proses pembesaran momen sesuai dengan pasal-pasal yang terdapat pada SNI 1726:2002, tepatnya pada persaman (2.63) sampai dengan persamaan (2.65), berikut perhitungannya :

$$
\begin{aligned}
& \frac{k_{x} \cdot L}{r_{x}}=\frac{0,80 \cdot 3500}{147}=19,048 \\
& N_{c r}=\frac{\pi^{2} \cdot E \cdot A_{g}}{\left(\frac{k L}{r}\right)^{2}} \\
& N_{c r}=107941,889 \mathrm{KN} \\
& C_{m}=0,6-0,4 \cdot \frac{M_{1}}{M_{2}} \\
& C m=1,00 \\
& \delta \quad=\frac{C_{m}}{1-\frac{N_{u}}{N_{c r}}} \\
& \delta \quad=1,003>1,0
\end{aligned}
$$

\section{Momen Maksimum Terfaktor}

Untuk memperoleh perhitungan yang memenuhi standar keamanan, maka dilakukan proses pemfaktoran momen maksium sesuai dengan pasalpasal yang terdapat pada SNI 1726:2002, tepatnya pada persamaan (2.61), berikut perhitungannya :

$$
\begin{aligned}
& M_{\text {ntu }} \quad=138,59 K N . m+\delta s M_{\text {ltu }}=0 \\
& M_{u}=\delta b M_{n t u}+\delta s M_{\text {ltu }} \\
&=138,96+0 \\
&=138,96
\end{aligned}
$$

\section{Menentukan Parameter Kelangsingan}

Untuk memperoleh perhitungan yang memenuhi standar keamanan, perlu dilakukan proses penentuan parameter kelangsingan profil sesuai dengan pasal-pasal yang terdapat pada SNI 1726:2002, tepatnya pada persamaan (2.53) berikut perhitungannya :

$$
\begin{aligned}
& \lambda_{\mathrm{c}}= \\
& \frac{1}{\pi} \cdot \frac{\mathrm{L}_{\mathrm{k}}}{\mathrm{r}_{\mathrm{y}}} \cdot \sqrt{\frac{\mathrm{f}_{\mathrm{y}}}{\mathrm{E}}}
\end{aligned}
$$

$\lambda c=0,46$

2

$$
\frac{\text { ? }}{\frac{1,43}{1,6-0,67 \text {. 回回 }}}=
$$

$\omega$

$$
=1,108
$$

\section{Menentukan Nu / $\varnothing \mathrm{Nn}$}

Untuk mengetahui tingkat keamanan, perlu dilakukan proses penentuan rasio antara beban aksial maksimum profil, dengan berdasarkan persamaan ( 2.51 ) dan persamaan ( 2.54 ) berikut perhitungannya :

$$
\begin{aligned}
& N_{n}=A_{g} \cdot \frac{f_{y}}{\omega} \\
& N_{n}=4476,54 \mathrm{KN} \\
& \varnothing N_{n}=0,85 \times 4476,54 \\
& =3805,06 \mathrm{KN} \\
& \frac{N_{u}}{3 N_{n}}=\frac{294,39}{3805,06} \\
& =0,08<0,2
\end{aligned}
$$

\section{Interaksi aksial momen}

Berdasarkan rasio antara beban aksial maksimum profil, dengan mengacu padapasal yang terdapat pada SNI 1726:2002, tepatnya pada persamaan ( 2.54 ) dan ( 2.55 ) maka digunakan:

Karena $\frac{\mathrm{N}_{\mathrm{u}}}{2 \mathrm{~N}_{\mathrm{n}}}<0,2$, maka SNI mensyaratkan :

$\frac{\mathrm{Nu}}{2 . ?_{\mathrm{k}} \mathrm{Nn}}+\left(\frac{\mathrm{M}_{\mathrm{ux}}}{\text { ? } \mathrm{Mnx}}+\frac{\mathrm{M}_{\mathrm{uy}}}{\text { ?Mny }}\right) \leq 1.0$

$0,276<1,00 \quad$ (Profil Aman )

Tabel 10 : Rekapitulasi Perhitungan Balok Portal Arah Y-Y 


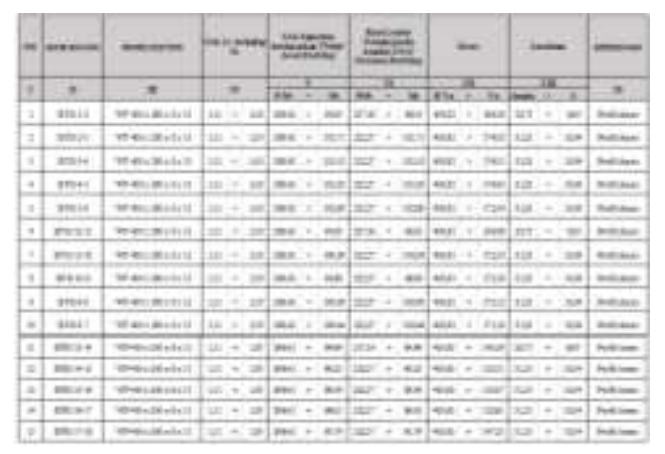

Tabel 11 : Rekapitulasi Perhitungan Kolom Portal Arah Y-Y

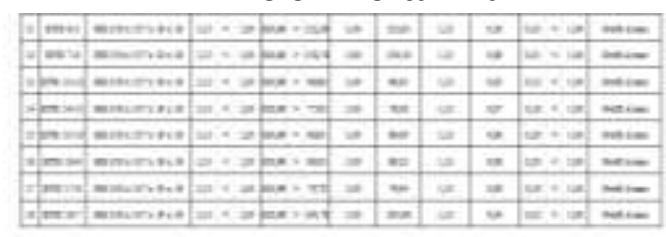

Tabel 12 : Rekapitulasi Perhitungan Balok Portal Arah X-X

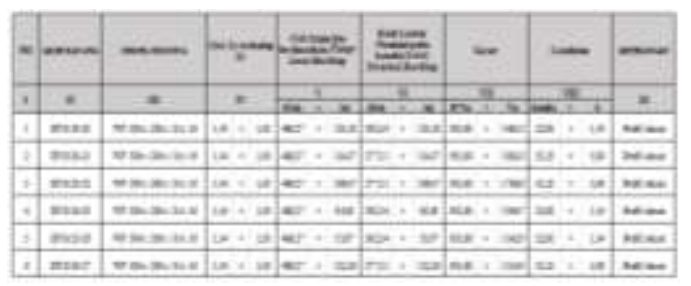

Tabel 13 : Rekapitulasi Perhitungan Kolom Portal Arah X-X

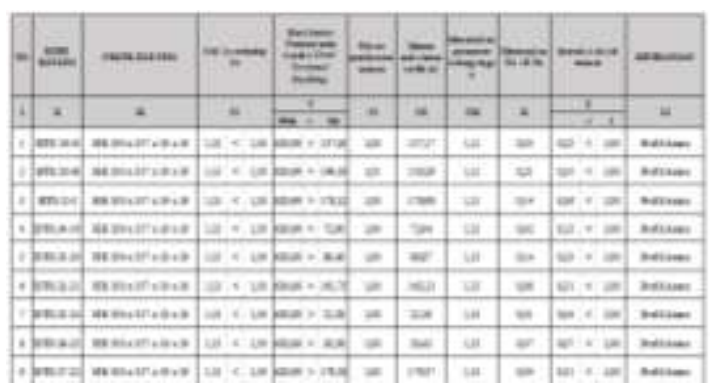

\section{KESIMPULAN}

Setelah dilakukan perhitungan dan pembahasan sesuai dengan masalah yang dibahas, maka dapat ditarik beberapa kesimpulan antara lain:

1. Setelah dilakukan proses perhitungan maka diketahui bahwa semua Balok Existing Portal Gedung PKU Muhammadiyah dikategorikanaman untuk menahan gaya-gayayang bekerja, dengan penjelasan sebagai berikut :

- Balok yang mengalami pengaruh gaya dalam (Momen dan gaya lintang) paling besar yaitu batang dengan kode 2-3 portal arah Y-Y, beban tersebut memikul beban $\mathrm{Mu}$ sebesar 101,71 KN dan gaya tekan aksial Vu sebesar 174,62 KN, lendutan yang terjadi sebesar 10,34 (syarat aman batang 2-3 = $31,2)$, profil WF $400 \times 200 \times 8 \times 13$ masih aman dalam memikul beban-beban tersebut.

- Balok yang mengalami pengaruh gaya dalam (Momen dan gaya lintang) paling kecil yaitu batang dengan kode 25-26 portal arah X-X , beban tersebut memikul beban $\mathrm{Mu}$ sebesar 55,67 KN dan gaya tekan aksial Vu sebesar 114,20 KN, lendutan yang terjadi sebesar 1,14 (syarat aman batang $25-26=$ 22,92), profil WF $500 \times 200 \times 10 \times$ 16 masih aman dalam memikul beban-beban tersebut.

2. Setelah dilakukan proses perhitungan maka diketahui bahwa semua KolomExisting Portal Gedung PKU Muhammadiyah dikategorikan amanuntuk menahan gaya-gaya yang bekerja, dengan penjelasan sebagai berikut :

- Kolom yang mengalami pengaruh gaya dalam (Momen dan gaya aksial tekan) paling besar yaitu batang dengan kode 3-C portal arah $Y-Y$, beban tersebut memikul beban Mu sebesar 185,05 KN dan gaya tekan aksial $\mathrm{Pu}$ sebesar $882,72 \mathrm{KN}$, dengan nilai perhitungan interaksi aksial momen 0,5 ( syarat aman $<1,00$ ), profil HB $350 \times 357 \times 19 \times 19$ masih aman dalam memikul beban-beban tersebut.

- Kolom yang mengalami pengaruh gaya dalam (Momen dan gaya aksial tekan) paling kecil yaitu batang dengan kode 25-24portal 
arah $\mathrm{X}-\mathrm{X}$, beban tersebut memikul beban $\mathrm{Mu}$ sebesar $21,38 \mathrm{KN}$ dan gaya tekan aksial Pu sebesar 44,48 $\mathrm{KN}$, dengan nilai perhitungan interaksi aksial momen 0,04 ( syarat aman $<1,00$ ), profil HB 350 x $357 \times 19$ x 19 masih aman dalam memikul beban-beban tersebut.

\section{SARAN}

Dari hasil analisis dan perhitungan yang telah dilakukan maka dapat diperoleh saran sebagai berikut :

1. Pada tahap awal perencanaan sebuah struktur gedung bertingkat diharapkan perencana/engineer dapat menentukan data-data perencanaan secara tepat, baik data mengenaik kondisi tanah, data bangunanbangunan disekitarnya dan data-data pendukung yang lainnya.

2. Pada tahap design / perencanaan diharapkan perencana telah memiliki feeling engineering dan pengetahuan tentang perhitungan struktur secara tepat, dikarenakan pekerjaan perencaan struktur adalah pekerjaan yang kompleks dan cukup beresiko pada pelaksanaannya, untuk itu diharapkan perencana dapat dengan cermat merencanakan suatu kontruksi yang aman dan juga mengakomodir dari segi estetika.

3. Perencana dituntut untuk mengikuti perkembangan zaman, sehingga output yang dihasilkan adalah sebuah karya yang up to datebaik dari segi estetika maupun dari segi strukturalnya, dalam hal ini perencana struktur diharuskan mampu mengikuti metode-metode perhitungan terbaru sebagai contoh untuk perhitungan gempa pemerintah telah mengeluarkan standar baru yaitu SKSNI 1726:2012 tentang "Tata cara perencanaan ketahanan gempa untuk struktur bangunan gedung dan non gedung " yang merupakan pengganti dari SK-SNI 1726:2002 tentang "Standar Perencanaan Ketahanan GempaUntuk Struktur Bangunan
Gedung", maka dari itu diharapkan bagi para perencana untuk selalu memperbaharui kemampuannya dalam perhitungan struktur dan aspek lainnya dalam ruang lingkup perencanaan.

4. Bagi pihak Owner atau pemilik proyek disarankan untuk dapat dengan teliti memilih rekanan baik rekanan dalam proses perencanaan, pelaksanaan dan pengawasan ( Konsultan Perencana, Kontraktor Pelaksan Dan Konsultan Pengawas/Supervisi ), teliti dalam arti menyeleksi dengan baik Track Recorddari rekanan sehingga pada proses pelaksanaan dapat berjalan dengan lancardan memperkecil peluang terjadinya kegagalan konstruksi.

5. Bagi pihak Pemerintah daerah disarankan untuk selalu mengawasi dengan baik setiap pelaksanaanpelaksanaan pembangunan khususnya pembangunan konstruksi gedung bertingkat, dengan cara berkoordinasi dengan dinas-dinas yang berhubungan langsung dengan pekerjaan-pekerjaan konstruksi seperti Dinas Pekerjaan Umum ( Dinas PU ) agar setiap proses pelaksanaan konstruksi berjalan dengan aman dan menghasilkan output bangunan yang sesuai dengan standar yang telah ditentukan.

6. Bagi masyarakat umum diharapkan lebih proaktif terhadap pengawasan pembangunan di daerah dalam hal ini khususnya pihak perwakilan masyarakat melalu lembaga swadaya masyarakat ( LSM ) guna selalu mengawasi dengan seksama untuk menghindari kecurangan-kecurangan yang biasa terjadi di lapangan.

7. Bagi pihak peneliti maupun civitas akademika diharapkan dengan berbagai kemajuan teknologi dan perkembangan literatur-literatur terbaru untuk mampu mengembangkan terobosanterobosan baru dalam proses pembangunan, agar selalu tercipta 
inovasi-inovasi dalam teknologi dan manajemen konstruksi.

8. Pada proses analisis portal PKU Muhammadiyah diperoleh hasil bahwa seluruh profil yang digunakan aman dalam memikul beban yang bekerja, namun dapat disarankan apabila dalam suatu perencanaan apabila ditemukan perhitungan yang dimana sebuah profil tidak mampu memikul beban yang bekerja saran yang dapat diberikan yaitu dilakukan analisis ulang dengan menggunakan profil yang lebih besar.

\section{DAFTAR PUSTAKA}

Amin, Dedy Khairul .2013 . Perhitungan Beban Aksial Kritis Pada Kolom Baja Dalam Sebuah Struktur Portal Baja.Sumatra Utara: Fakultas Teknik Universitas Sumatra Utara.

Amon, Rene dkk, 1988. Perencanaan Konstruksi Baja Untuk Insinyur dan Arsitek 1. PT.Pradnya Paramita, Jakarta.

Amon, Rene dkk, 1996. Perencanaan Konstruksi Baja Untuk Insinyur dan Arsitek 2. PT.Pradnya Paramita, Jakarta.

Badan Standarisasi Nasional. (2002). SNI 03-1729-2002: Tata Cara Perencanaan Struktur Baja Untuk Bangunan Gedung. Badan Standarisasi Nasional.

Badan Standarisasi Nasional. (2012). SNI 1726:2012: Tata cara perencanaan ketahanan gempa untuk struktur bangunan gedung dan non gedung. Badan Standarisasi Nasional.

Beta Patrianto, Wiryanto Dewobroto.2006. "Evaluasi Metode Perencanaan Batang Aksial Murni SNI-03-17292000 Dan AISC-LRFD", Surabaya.

Biondi. 2010. Perencanaan Portal Baja 4 Lantai Dengan Metode Plastisitas Dan Dibandingkan Dengan MetodeLRFD. Sumatra Utara: Fakultas Teknik Universitas Sumatra Utara.

Charles G. Salmon, Jhon E. Johnson. 1990. "Struktur Baja, Design dan
PerilakuJilid 1", Penerbit Airlangga, Jakarta,

Departemen Pekerjaan Umum, 1987. SKBI 1.3.53.1987 Pedoman Perencanaan Pembebanan untuk Rumah dan Gedung, Yayasan Badan Penerbit PU, Jakarta.

Frick,Heinz. 1979. "Statika dan Kegunaannya", Mekanika Teknik 2 Jilid II.Kanisius, Yogyakarta.

Gunawan, Rudy. (1987). TabelProfilKonstruksi Baja. Yogyakarta: Kanisius.

Indarto, Himawan dkk. 2013. Aplikasi SNI Gempa 1726:2012 for Dummies. Semarang : Fakultas Teknik Universitas Negeri Semarang.

Joseph E. Bowles.1985. "Desain Baja Konstruksi", Penerbit Erlangga. Jakarta,.

Khafis, Muhammad.2009. Perencanaan Struktur Baja Pada BangunanTujuh Lantai Sebagai Hotel. Surakarta: Fakultas Teknik Universitas Sebelas Maret.

Oentoeng, 2004. Konstruksi Baja. ANDI, Yogyakarta.

Pramono, Handi dkk. 2007. 12 Tutorial Latihan Desain Konstruksi Dengan SAP2000 Versi 9. Andi, Yogyakarta.

Purnama, A, 2011. Studi Kelayakan Pembangunan Pembangkit Listrik Tenaga Mikrohidro Studi Kasus: PLTMH Minggir pada saluran irigasi Minggir di Padukuhan Klagaran Desa Sendangrejo Kecamatan Minggir Kabupaten Sleman, Jurnal Unsa Progress. Vol.10, No.15, Oktober, Universitas Samawa, Sumbawa Besar. 